\title{
Determination of Natural Radioactivity and Associated Radiological Risk in Building Materials Used in Tabuk Area, Saudi Arabia
}

\author{
Shams A M Issa ${ }^{1,2, *}$ and S M Alaseri ${ }^{2}$ \\ ${ }^{1}$ Physics department, Faculty of Science, Al-Azhar University, Egypt \\ ${ }^{2}$ Physics department, Faculty of Science, University of Tabuk, Saudi Arabia \\ shams_issa@yahoo.com
}

\begin{abstract}
The concentrations of ${ }^{226} \mathrm{Ra},{ }^{232} \mathrm{Th}$ and ${ }^{40} \mathrm{~K}$ in the commonly used building materials of Tabuk area, Saudi Arabia were measured using $\gamma$-ray spectrometry. The mean activity concentration with standard deviation was found to be $27.52 \pm 11.28,37.44 \pm 14.51$ and $175.52 \pm 113.87 \mathrm{Bqkg}^{-1}$ and ranged from 11.11 to $52.58 \mathrm{Bqkg}^{-1}, 10.99$ to $59.72 \mathrm{Bqkg}^{-1}$, 60.70 to $394.46 \mathrm{Bqkg}^{-1}$ for, ${ }^{226} \mathrm{Ra},{ }^{232} \mathrm{Th}^{2}$ and ${ }^{40} \mathrm{~K}$, respectively. The associated radiological hazards of natural radioactivity in the studied materials were evaluated by radium equivalent activity, external hazard index, internal hazard index, indoor air absorbed dose rate and annual effective dose rate. Basic statistics and frequency distributions for all radionuclides were used to describe the statistical characteristics of the radionuclide activities. This data will serve as the baseline level for naturally occurring radionuclides in the study area and will be useful for tracking and assessing any pollution inventory in the environment of this region.
\end{abstract}

Keywords: Natural radioactivity, Building materials, Gamma spectrometry, Dose, Hazard indices

Keywords: Natural radioactivity, Building materials, Gamma spectrometry, Dose, Hazard indices

\section{Introduction}

Humans are exposed to ambient ionizing radiation from ${ }^{40} \mathrm{~K}$, the ${ }^{238} \mathrm{U}$ and ${ }^{232} \mathrm{Th}$ series and their decay products which widely spread in the earth's environment. The interested radionuclides in the research about environmental radioactivity $\operatorname{are}^{226} \mathrm{Ra},{ }^{232} \mathrm{Th}$ and ${ }^{40} \mathrm{~K}$, among which ${ }^{226} \mathrm{Ra}$ are a radionuclide in the ${ }^{238}$ Useries and ${ }^{232} \mathrm{Th}$ is the first member in the ${ }^{232} \mathrm{Th}$ series. The natural radionuclides in building materials are responsible for the external and internal radiation exposures of individuals living in dwellings [1].Generally, the specific activities of ${ }^{238} \mathrm{U},{ }^{232} \mathrm{Th}$ and ${ }^{40} \mathrm{~K}$ in raw building materials and their products depend on geological and geographical conditions as well as the geochemical features of those materials. The assessment of the population's exposure to indoor radiation is very important; therefore, knowledge regarding the concentration of natural radionuclides in construction materials is required. Construction materials are derived from both natural sources (e.g., rock and soil) and waste products (e.g., phosphor gypsum, alum shale, coal, fly ash, oil-shale ash, some rare minerals and certain slugs) as well as from industry products (e.g., power plants, phosphate fertilizer and the oil industry) [2]. Although building materials act as sources of radiation to the inhabitants in dwellings, they also shield against outdoor radiation [3]. Knowing the level of the natural radioactivity in building materials is important to assess the associated radiological hazards to human health and to develop standards and guidelines for the use and management of these 
materials [4]. In the present work, the concentration of natural radionuclides and associated radiological risk were measured in 35 samples of building materials that were commonly used in Tabuk, Saudi Arabia, using gamma spectrometry. The obtained results were compared to the recommended values to assess the radiation hazards to humans resulting from the building materials, and these results were also compared to the corresponding values of building materials from different countries. The radiological data were processed using multivariate statistical methods such as the Pearson correlation coefficient as well as cluster and principal component analyses to determine the similarities and correlations among the various samples.

\section{Materials and Methods}

\subsection{Sample Collection and Preparation}

A total of 35 samples of natural and manufactured building materials commonly used in Tabuk city, Egypt were collected randomly from sites where housing and other building were constructed and from the building material suppliers for the measurement of the specific radioactivity of ${ }^{226} \mathrm{Ra},{ }^{232} \mathrm{Th}$ and ${ }^{40} \mathrm{~K}$. Deposit samples were oven dried at a temperature of $105^{\circ} \mathrm{C}$ for $12 \mathrm{~h}$ and sieved through a 200 mesh. The dried samples were transferred to polyethylene Marinelli beakers. Each deposit sample was left for at least 4 weeks to reach secular equilibrium between radium and thorium, and their progenies [5].

\subsection{Gamma-ray Spectroscopic Technique}

Activity measurements have been performed by gamma ray spectrometer, employing a scintillation detector $(3 \times 3$ inch). It is hermetically sealed assembly, which includes a NaI (Tl) crystal, coupled to PC-MCA Canberra Accuspec. To reduce gamma ray background, a cylindrical lead shield (100 mm thick) with a fixed bottom and movable cover shielded the detector. The lead shield contained an inner concentric cylinder of copper $(0.3 \mathrm{~mm}$ thick) in order to absorb X-rays generated in the lead. In order to determine the background distribution in the environment around the detector an empty sealed beaker was counted in the same manner and in the same geometry as the samples. The measurement time of activity or background was $43200 \mathrm{~s}$. The background spectra were used to correct the net peak area of gamma rays of measured isotopes. A dedicated software program, Genie 2000 from Canberra, was used to carry out the on-line analysis of each measured gamma-ray spectrum. The ${ }^{226} \mathrm{Ra}$ radionuclide was estimated from the $351.9 \mathrm{keV}(36.7 \%) \gamma$-peak of ${ }^{214} \mathrm{~Pb}$ and $609.3 \mathrm{keV}(46.1 \%), 1120.3 \mathrm{keV}(15 \%), 1728.6$ $\mathrm{keV}(3.05 \%)$ and $1764 \mathrm{keV}(15.9 \%) \gamma$-peaks of ${ }^{214} \mathrm{Bi}$. The $186 \mathrm{keV}$ photon peak of ${ }^{226} \mathrm{Ra}$ was not used because of the interfering peak of ${ }^{235} \mathrm{U}$ with energy of $185.7 \mathrm{keV} .{ }^{232} \mathrm{Th}$ radionuclide was estimated from the $911.2 \mathrm{keV}(29 \%) \gamma$-peak of ${ }^{228} \mathrm{Ac}, 238.6 \mathrm{keV}$ (43.6\%) $\gamma$-peak of ${ }^{212} \mathrm{~Pb}$ and $583.1 \mathrm{kev}(84.5) \gamma$-peak of ${ }^{208} \mathrm{Tl} .{ }^{40} \mathrm{~K}$ radionuclide was estimated using $1,461 \mathrm{keV}(10.7 \%) \gamma$-peak from ${ }^{40} \mathrm{~K}$ itself. All procedures were described in previous publications [6].

\section{Results and Discussion}

\subsection{Specific Radioactivity}

The distribution of the detected radionuclides, ${ }^{226} \mathrm{Ra},{ }^{232} \mathrm{Th}$, and ${ }^{40} \mathrm{~K}$, in the 35 building samples are shown in Figure 1. As seen in Table 1, the activity concentration range for ${ }^{226} \mathrm{Ra},{ }^{232} \mathrm{Th}$, and ${ }^{40} \mathrm{Kwas}$ from 11.11 to $52.58 \mathrm{Bqkg}^{-1}, 10.99$ to $59.72 \mathrm{Bqkg}^{-1}, 60.70$ to $394.46 \mathrm{Bqkg}^{-1}$, respectively. The average concentration of ${ }^{226} \mathrm{Ra},{ }^{232} \mathrm{Th}$, and ${ }^{40} \mathrm{~K}$ was 27.52 , 37.44 and $175.52 \mathrm{Bqkg}^{-1}$, respectively. These values are $21.37,24.80$ and $56.12 \%$ lower than the recommended world average values for ${ }^{226} \mathrm{Ra},{ }^{232} \mathrm{Th}$, and ${ }^{40} \mathrm{~K}$, respectively (Table 
1), which are 35,30 and $400 \mathrm{~Bq} \mathrm{~kg}{ }^{-1}$ for ${ }^{226} \mathrm{Ra},{ }^{232} \mathrm{Th}$ and ${ }^{40} \mathrm{~K}$, respectively [7].The highest values observed for the specific activities of ${ }^{226} \mathrm{Ra},{ }^{232} \mathrm{Th}$ and ${ }^{40} \mathrm{~K}$ are $52.58 \pm 5$.8in cement $(\mathrm{Ce}-4), 59.72 \pm 6.6 \mathrm{in}$ cement $(\mathrm{Ce}-5)$ and $394.4 \pm 44.2 \mathrm{~Bq} \mathrm{~kg}{ }^{-1}$ in granite (Gran-2), respectively, while the lowest observed values of the specific activities of the same radionuclides are 11.11 \pm 1.2 in gravel (Grav-2), 10.99 $\pm 1.2 \mathrm{in}$ marble (Ma-3) and $60.70 \pm 6.8 \mathrm{~Bq} \mathrm{~kg}^{-1}$ in limestone (Li-3), respectively. Figure 2 shows that, the concentrations of ${ }^{226} \mathrm{Ra},{ }^{232} \mathrm{Th}$ and ${ }^{40} \mathrm{~K}$ occupy the total activity of $3.77 \%$ in sand $(\mathrm{Sa}-2)$ to $22.72 \%$ in limestone (Li-5), $5.47 \%$ in sand (Sa-2) to $34.13 \%$ in limestone (Li-1) and $40.90 \%$ in limestone (Li-5) to $90.76 \%$ in sand (Sa-2), respectively, which indicates that the specific activity due to ${ }^{40} \mathrm{~K}$ is the largest contributor to the total activity for all samples.

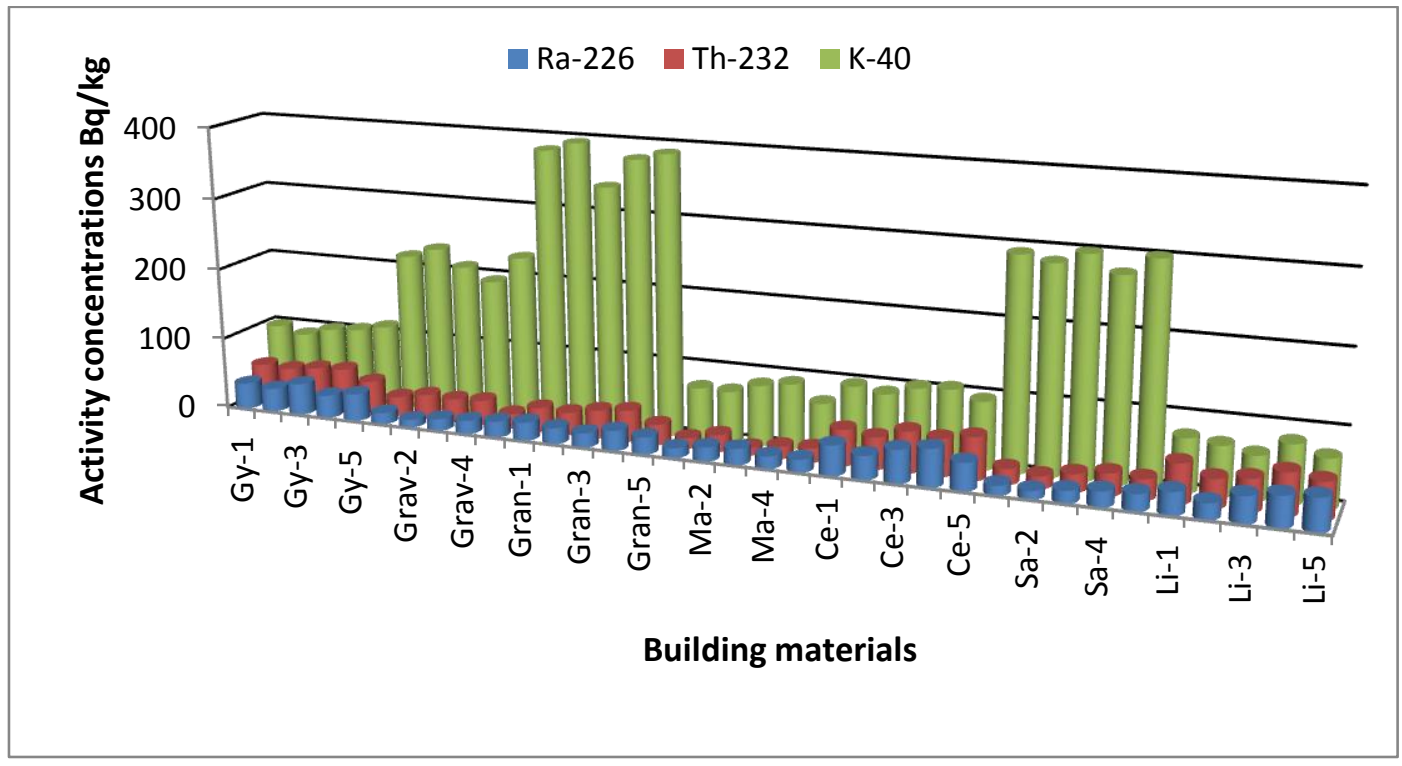

Figure 1. Activity Concentrations of ${ }^{226} \mathrm{Ra},{ }^{232} \mathrm{Th}$ and ${ }^{40} \mathrm{~K}$ in Building Materials

Table 1. Summary of Activity Concentrations ${ }^{226} \mathrm{Ra},{ }^{232} \mathrm{Th}$ and ${ }^{40} \mathrm{~K}$ in Building Materials

\begin{tabular}{cccccccc}
\hline Radionuclides & $\begin{array}{c}\text { Minimum } \\
\mathrm{Bq} \mathrm{kg}^{-1}\end{array}$ & $\begin{array}{c}\text { Maximum } \\
\mathrm{Bq} \mathrm{kg}^{-1}\end{array}$ & $\begin{array}{c}\text { Mean } \\
\mathrm{Bq} \mathrm{kg}^{-1}\end{array}$ & $\begin{array}{c}\text { Standard } \\
\text { deviation }\end{array}$ & Median & $\begin{array}{c}\text { World } \\
\text { average } \\
\mathrm{Bq} \mathrm{kg}^{-1}\end{array}$ & $\begin{array}{c}\text { Increase/decrease of } \\
\text { mean with world } \\
\text { average in \% }\end{array}$ \\
\hline${ }^{226} \mathrm{Ra}$ & 11.11 & 52.58 & 27.52 & 11.28 & 23.43 & $35^{\mathrm{a}}$ & $(-) 21.37$ \\
${ }^{232} \mathrm{Th}$ & 10.99 & 59.72 & 37.44 & 14.51 & 34.97 & $30^{\mathrm{a}}$ & $(-) 24.80$ \\
${ }^{40} \mathrm{~K}$ & 60.70 & 394.46 & 175.52 & 113.87 & 104.53 & $400^{\mathrm{a}}$ & $(-) 56.12$ \\
\hline
\end{tabular}

${ }^{\mathrm{a}}$ UNSCEAR (1988).

(-) Represents decrease in value. 


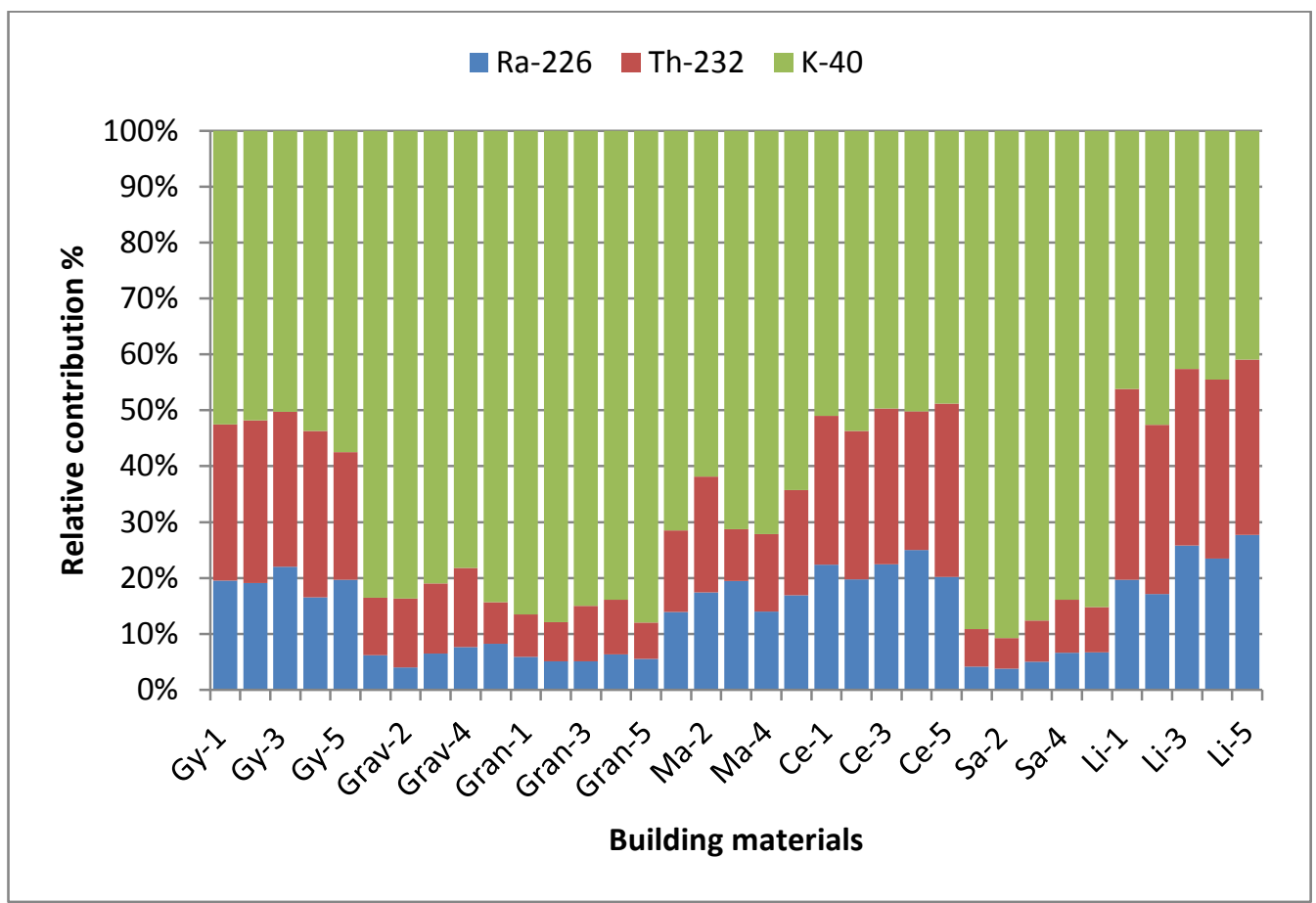

Figure 2. The Relative Concentration of ${ }^{226} \mathrm{Ra},{ }^{232} \mathrm{Th}$ and ${ }^{40} \mathrm{~K}$ to the Total Activity in Building Materials

\subsection{Radium Equivalent Activities $\left(R a_{\text {eq }}\right)$}

The ${ }^{226} \mathrm{Ra},{ }^{232} \mathrm{Th}$ and ${ }^{40} \mathrm{~K}$ emit different $\gamma$-doses even if present in the same amount in any material. So the radiation hazards of a material are estimated by calculating the net effect of ${ }^{226} \mathrm{Ra},{ }^{232} \mathrm{Th}$ and ${ }^{40} \mathrm{~K}$ present in the material as radium equivalent activity $\left(R a_{\mathrm{eq}}\right)$. During this study $\left(R a_{\text {eq }}\right)$ was calculated using the following equation by Ibrahiem[8].

$R a_{e q}=A_{R a}+1.43 A_{T h}+0.077 A_{K}$

The $A_{\mathrm{Ra}}, A_{\mathrm{Th}}$ and $A_{\mathrm{K}}$ represent the activity concentrations of ${ }^{226} \mathrm{Ra},{ }^{232} \mathrm{Th}$, and ${ }^{40} \mathrm{~K} \mathrm{~Bq} \mathrm{~kg}$ ${ }^{1}$, respectively. It has been assumed here that $370 \mathrm{~Bq} \mathrm{~kg}^{-1}$ of ${ }^{238} \mathrm{U}$ or $259 \mathrm{~Bq} \mathrm{~kg}^{-1} \mathrm{of}^{232} \mathrm{Th}$ or $4810 \mathrm{~Bq} \mathrm{~kg}{ }^{-1} \mathrm{of}^{40} \mathrm{~K}$ produce the same gamma dose rate. $R a_{\mathrm{eq}}$ is related to the external $\gamma$ dose and internal dose due to radon and its daughters. Table 2 presents the radium equivalent activity, $R a_{\mathrm{eq}}$ in building material samples. As seen in Table 3 the radium equivalent activity ranges from $40.44 \mathrm{~Bq} \mathrm{~kg}$ to $136.43 \mathrm{~Bq} \mathrm{~kg}{ }^{-1}$ with a mean value of $94.59 \mathrm{~Bq} \mathrm{~kg}$. This value is $74.43 \%$ lower than the recommended safe limit $370 \mathrm{~Bq} \mathrm{~kg}^{-}$ ${ }^{1}[9] .{ }^{232} \mathrm{Th}$ is the main contributor to $R a_{\mathrm{eq}}$ in all samples, except in marble (Ma-3) the main contributor to $R a_{\text {eq }}$ is ${ }^{226} \mathrm{Ra}$. The sum of the relative contribution of ${ }^{226} \mathrm{Ra}$ and ${ }^{232} \mathrm{Th}$ to $R a_{\mathrm{eq}}$ is $62.39-95.84 \%$ in all analyzed building materials (Figure 3). Table 4 presented a comparison of activity concentrations and radium equivalent activities $\left(\mathrm{Bq} \mathrm{kg}^{-1}\right)$ in gypsum, gravels, granite, marble, cement and sand in different areas of the world, respectively.

\subsection{Representative Level Index (RLI)}

The $\gamma$-ray representative index is used as a tool to estimate the radiation hazards in building materials associated with natural radionuclide. It is defined by the following equation [2]:

$\mathrm{RLI}=\left(\mathrm{A}_{\mathrm{Ra}} / 150\right)+\left(\mathrm{A}_{\mathrm{Th}} / 100\right)+\left(\mathrm{A}_{\mathrm{K}} / 1500\right)$ 
Table 2. Radium Equivalent $\left(R a_{\text {eq }}\right)\left(B q \mathrm{~kg}^{-1}\right)$, Representative Level Index (RLI)(Bq kg ${ }^{-1}$ ), Activity Utilization Index (AUI), Outdoor Absorbed Dose Rate $\left(D_{\text {out }}\right)\left(n G y h^{-1}\right)$, Indoor Absorbed Dose Rate $\left(D_{\text {in }}\right)\left(n G y h^{-1}\right)$, Outdoor Annual Effective Dose $\left(E_{\text {out }}\right)\left(\mathrm{mSv} \mathrm{y}^{-1}\right)$, Indoor Annual Effective Dose $\left(E_{\text {in }}\right)\left(\mathrm{mSv}^{-1}\right)$, External Radiation Hazard $\left(\boldsymbol{H}_{\mathrm{ex}}\right)$, Enteral Radiation Hazard $\left(\boldsymbol{H}_{\mathrm{in}}\right)$, Outdoor Excess Lifetime Cancer Risk ( $E L C R_{\text {out }}$ ), Indoor Excess Lifetime Cancer Risk $\left(E L C R_{\text {in }}\right)$ and Annual Gonadal Dose Equivalent (AGDE)( $\left.\mu S v y^{-1}\right)$

\begin{tabular}{|c|c|c|c|c|c|c|c|c|c|c|c|c|c|c|c|}
\hline Materials & $\begin{array}{l}\text { Sample } \\
\text { code }\end{array}$ & $R a_{\text {oq }}$ & RLI & AUI & $D_{\text {out }}$ & $\overline{D_{\text {in }}}$ & $E_{\text {out }}$ & $E_{\text {in }}$ & $I_{a}$ & $I_{\gamma}$ & $H_{e x}$ & $H_{\text {in }}$ & $\begin{array}{c}E L C R_{\text {out }} \\
\times 10^{-4}\end{array}$ & $\begin{array}{c}E L C R_{\text {in }} \\
\times 10^{-3}\end{array}$ & AGDE \\
\hline Gypsum-1 & Gy-1 & 119.12 & 0.83 & 0.98 & 51.45 & 99.29 & $\overline{0.06}$ & 0.49 & 0.18 & 0.42 & $\overline{0.32}$ & $\overline{0.42}$ & $\overline{2.2}$ & 1.7 & 363.07 \\
\hline Gypsum-2 & Gy-2 & 112.31 & 0.79 & 0.92 & 48.46 & 93.35 & 0.06 & 0.46 & 0.17 & 0.39 & 0.30 & 0.39 & 2.1 & 1.6 & 341.81 \\
\hline Gypsum-3 & Gy-3 & 131.58 & 0.92 & 1.09 & 56.83 & 110.08 & 0.07 & 0.54 & 0.22 & 0.46 & 0.36 & 0.47 & 2.4 & 1.9 & 400.98 \\
\hline Gypsum-4 & Gy-4 & 123.09 & 0.86 & 1.01 & 53.10 & 101.81 & 0.07 & 0.50 & 0.16 & 0.43 & 0.33 & 0.42 & 2.3 & 1.7 & 374.47 \\
\hline Gypsum-5 & Gy-5 & 111.11 & 0.78 & 0.91 & 48.27 & 93.74 & 0.06 & 0.46 & 0.19 & 0.39 & 0.30 & 0.40 & 2.1 & 1.6 & 341.24 \\
\hline Gravels-1 & Grav-1 & 71.40 & 0.52 & 0.49 & 32.25 & 62.12 & 0.04 & 0.30 & 0.08 & 0.26 & 0.19 & 0.24 & 1.4 & 1.1 & 230.83 \\
\hline Gravels-2 & Grav-2 & 77.86 & 0.57 & 0.53 & 34.99 & 66.62 & 0.04 & 0.33 & 0.06 & 0.29 & 0.21 & 0.24 & 1.5 & 1.1 & 250.07 \\
\hline Gravels-3 & Grav-3 & 79.58 & 0.58 & 0.57 & 35.60 & 68.31 & 0.04 & 0.34 & 0.08 & 0.29 & 0.21 & 0.26 & 1.5 & 1.2 & 254.08 \\
\hline Gravels-4 & Grav-4 & 83.82 & 0.60 & 0.61 & 37.26 & 71.54 & 0.05 & 0.35 & 0.09 & 0.30 & 0.23 & 0.28 & 1.6 & 1.2 & 265.35 \\
\hline Gravels-5 & Grav-5 & 69.12 & 0.51 & 0.47 & 31.51 & 61.54 & 0.04 & 0.30 & 0.11 & 0.25 & 0.19 & 0.25 & 1.4 & 1.1 & 226.21 \\
\hline Granite-1 & Gran-1 & 103.19 & 0.76 & 0.68 & 47.28 & 91.59 & 0.06 & 0.45 & 0.13 & 0.38 & 0.28 & 0.35 & 2.0 & 1.6 & 339.92 \\
\hline Granite-2 & Gran-2 & 98.33 & 0.73 & 0.62 & 45.31 & 87.68 & 0.06 & 0.43 & 0.11 & 0.37 & 0.27 & 0.33 & 1.9 & 1.5 & 326.33 \\
\hline Granite-3 & Gran-3 & 102.41 & 0.75 & 0.69 & 46.43 & 89.18 & 0.06 & 0.44 & 0.10 & 0.38 & 0.28 & 0.33 & 2.0 & 1.5 & 332.75 \\
\hline Granite-4 & Gran-4 & 120.44 & 0.88 & 0.83 & 54.51 & 105.17 & 0.07 & 0.52 & 0.14 & 0.44 & 0.33 & 0.40 & 2.3 & 1.8 & 390.43 \\
\hline Granite-5 & Gran-5 & 95.14 & 0.71 & 0.60 & 43.94 & 85.30 & 0.05 & 0.42 & 0.12 & 0.35 & 0.26 & 0.32 & 1.9 & 1.5 & 316.68 \\
\hline Marble-1 & Ma-1 & 40.44 & 0.29 & 0.31 & 17.86 & 34.78 & 0.02 & 0.17 & 0.07 & 0.14 & 0.11 & 0.15 & 77 & 60 & 126.92 \\
\hline Marble-2 & Ma-2 & 59.62 & 0.42 & 0.48 & 25.99 & 50.43 & 0.03 & 0.25 & 0.10 & 0.21 & 0.16 & 0.22 & 1.1 & 87 & 183.95 \\
\hline Marble-3 & $\mathrm{Ma}-3$ & 45.05 & 0.32 & 0.35 & 20.06 & 39.93 & 0.02 & 0.20 & 0.11 & 0.16 & 0.12 & 0.18 & 86 & 69 & 142.97 \\
\hline Marble-4 & $\mathrm{Ma}-4$ & 49.37 & 0.35 & 0.38 & 21.83 & 42.58 & 0.03 & 0.21 & 0.09 & 0.18 & 0.13 & 0.18 & 94 & 73 & 155.27 \\
\hline Marble-5 & Ma-5 & 51.59 & 0.36 & 0.41 & 22.56 & 43.87 & 0.03 & 0.22 & 0.09 & 0.18 & 0.14 & 0.19 & 97 & 75 & 159.84 \\
\hline Cement-1 & Ce-1 & 121.56 & 0.85 & 1.01 & 52.55 & 101.97 & 0.06 & 0.50 & 0.21 & 0.42 & 0.33 & 0.44 & 2.3 & 1.8 & 370.95 \\
\hline Cement-2 & Ce-2 & 103.97 & 0.73 & 0.85 & 44.97 & 86.95 & 0.06 & 0.43 & 0.17 & 0.36 & 0.28 & 0.37 & 1.9 & 1.5 & 317.48 \\
\hline Cement-3 & Ce-3 & 136.43 & 0.95 & 1.13 & 58.91 & 114.16 & 0.07 & 0.56 & 0.23 & 0.48 & 0.37 & 0.49 & 2.5 & 2.0 & 415.65 \\
\hline Cement-4 & $\mathrm{Ce}-4$ & 135.63 & 0.94 & 1.13 & 58.71 & 114.56 & 0.07 & 0.56 & 0.26 & 0.47 & 0.37 & 0.51 & 2.5 & 2.0 & 414.63 \\
\hline Cement-5 & Ce-5 & 131.57 & 0.92 & 1.09 & 56.67 & 109.13 & 0.07 & 0.54 & 0.19 & 0.46 & 0.36 & 0.46 & 2.4 & 1.9 & 399.45 \\
\hline Sand-1 & Sa-1 & 67.22 & 0.50 & 0.41 & 31.14 & 60.09 & 0.04 & 0.29 & 0.07 & 0.25 & 0.18 & 0.22 & 1.3 & 1.0 & 224.65 \\
\hline Sand-2 & Sa-2 & 58.04 & 0.44 & 0.34 & 27.19 & 52.59 & 0.03 & 0.26 & 0.06 & 0.22 & 0.16 & 0.19 & 1.2 & 90 & 196.83 \\
\hline
\end{tabular}

Table 2. Continue

\begin{tabular}{llllllllllllllll}
\hline Materials & $\begin{array}{l}\text { Sample } \\
\text { code }\end{array}$ & $R a_{\text {oq }}$ & RLI & AUI & $D_{\text {out }}$ & $D_{\text {in }}$ & $E_{\text {out }}$ & $E_{\text {in }}$ & $I_{a}$ & $I_{\text {y }}$ & $H_{\text {ax }}$ & $H_{\text {in }}$ & $\begin{array}{c}\text { ELCR out } \\
\times 10^{-4}\end{array}$ & $\begin{array}{c}E L C R_{\text {in }} \\
\times 10^{-3}\end{array}$ & AGDE \\
\hline Sand-3 & Sa-3 & 76.04 & 0.56 & 0.49 & 34.97 & 67.59 & 0.04 & 0.33 & 0.09 & 0.28 & 0.21 & 0.25 & 1.5 & 1.2 & 251.71 \\
Sand-4 & Sa-4 & 87.48 & 0.64 & 0.60 & 39.62 & 76.55 & 0.05 & 0.38 & 0.11 & 0.32 & 0.24 & 0.29 & 1.7 & 1.3 & 283.82 \\
Sand-5 & Sa-5 & 87.48 & 0.64 & 0.59 & 39.88 & 77.35 & 0.05 & 0.38 & 0.12 & 0.32 & 0.24 & 0.30 & 1.7 & 1.3 & 286.29 \\
Limestone-1 & Li-1 & 115.25 & 0.81 & 0.96 & 49.51 & 95.00 & 0.06 & 0.47 & 0.16 & 0.40 & 0.31 & 0.40 & 2.1 & 1.6 & 348.70 \\
Limestone-2 & Li-2 & 84.12 & 0.59 & 0.69 & 36.27 & 69.57 & 0.04 & 0.34 & 0.11 & 0.29 & 0.23 & 0.29 & 1.6 & 1.2 & 255.73 \\
Limestone-3 & Li-3 & 105.70 & 0.73 & 0.89 & 45.48 & 88.17 & 0.06 & 0.43 & 0.18 & 0.37 & 0.29 & 0.38 & 2.0 & 1.5 & 320.50 \\
Limestone-4 & Li-4 & 131.80 & 0.92 & 1.10 & 56.70 & 109.56 & 0.07 & 0.54 & 0.21 & 0.46 & 0.36 & 0.47 & 2.4 & 1.9 & 399.56 \\
Limestone-5 & Li-5 & 123.80 & 0.86 & 1.04 & 53.27 & 103.52 & 0.07 & 0.51 & 0.23 & 0.43 & 0.33 & 0.46 & 2.3 & 1.8 & 375.39 \\
\hline
\end{tabular}


Table 3. Summary of Radiation Indices: $R a_{\text {eq }}, R L I, A U I, D_{\text {out }}, D_{\text {in }}, E_{\text {out }}, E_{\text {in }}, I_{\alpha}$, $I_{\mathrm{y}}, H_{\mathrm{ex}}, H_{\text {in }}, E L C R_{\text {out }}, E L C R_{\text {in }}$ and AGDE, in Building Materials

\begin{tabular}{lccccccc}
\hline Radiation indices & Minimum & Maximum & Mean & $\begin{array}{c}\text { Standard } \\
\text { deviation }\end{array}$ & Median & $\begin{array}{c}\text { Upper } \\
\text { limit }\end{array}$ & $\begin{array}{c}\text { Increase/decrease of } \\
\text { mean with Upper } \\
\text { limit in \% }\end{array}$ \\
\hline $\mathrm{Ra}_{\mathrm{eq}}$ & & & & & & & $(-) 74.43$ \\
$\mathrm{RLI}$ & 40.44 & 136.43 & 94.59 & 28.46 & 98.33 & 370 & $(-) 73$ \\
$\mathrm{AUI}$ & 0.29 & 0.95 & 0.67 & 0.19 & 0.73 & $\leq 1$ & $(-) 33$ \\
$\mathrm{D}_{\text {out }}$ & 0.31 & 1.13 & 0.72 & 0.26 & 0.68 & $<2$ & $(-) 64$ \\
$\mathrm{D}_{\text {in }}$ & 17.86 & 58.91 & 41.75 & 11.99 & 44.97 & 59 & $(-) 29.23$ \\
$\mathrm{E}_{\text {out }}$ & 34.78 & 114.56 & 80.73 & 11.99 & 86.95 & 84 & $(-) 3.89$ \\
$\mathrm{E}_{\text {in }}$ & 0.02 & 0.07 & 0.05 & 0.01 & 0.06 & 0.07 & $(-) 28.57$ \\
$\mathrm{I}_{\alpha}$ & 0.17 & 0.56 & 0.39 & 0.11 & 0.43 & 0.41 & $(-) 4.87$ \\
$\mathrm{I}_{\gamma}$ & 0.06 & 0.26 & 0.13 & 0.05 & 0.12 & $\leq 1$ & $(-) 87$ \\
$\mathrm{H}_{\text {ex }}$ & 0.14 & 0.48 & 0.33 & 0.09 & 0.36 & $\leq 1$ & $(-) 67$ \\
$\mathrm{H}_{\text {in }}$ & 0.11 & 0.37 & 0.25 & 0.07 & 0.27 & $\leq 1$ & $(-) 75$ \\
$\mathrm{ELCR}_{\text {out }} \times 10^{-3}$ & 0.15 & 0.51 & 0.32 & 0.10 & 0.33 & $\leq 1$ & $(-) 68$ \\
$\mathrm{ELCR}_{\text {in }} \times 10^{-3}$ & 0.08 & 0.25 & 0.18 & 0.05 & 0.20 & 0.29 & $(-) 37.93$ \\
$\mathrm{AGDE}$ & 0.60 & 2.00 & 1.40 & 0.40 & 1.50 & 1.16 & $(+) 20.68$ \\
\hline & 126.92 & 415.65 & 296.7 & 84.10 & 317.48 & 300 & $(-) 1.1$ \\
\hline
\end{tabular}

$(-)$ and (+) represent decrease and increase in value, respectively.

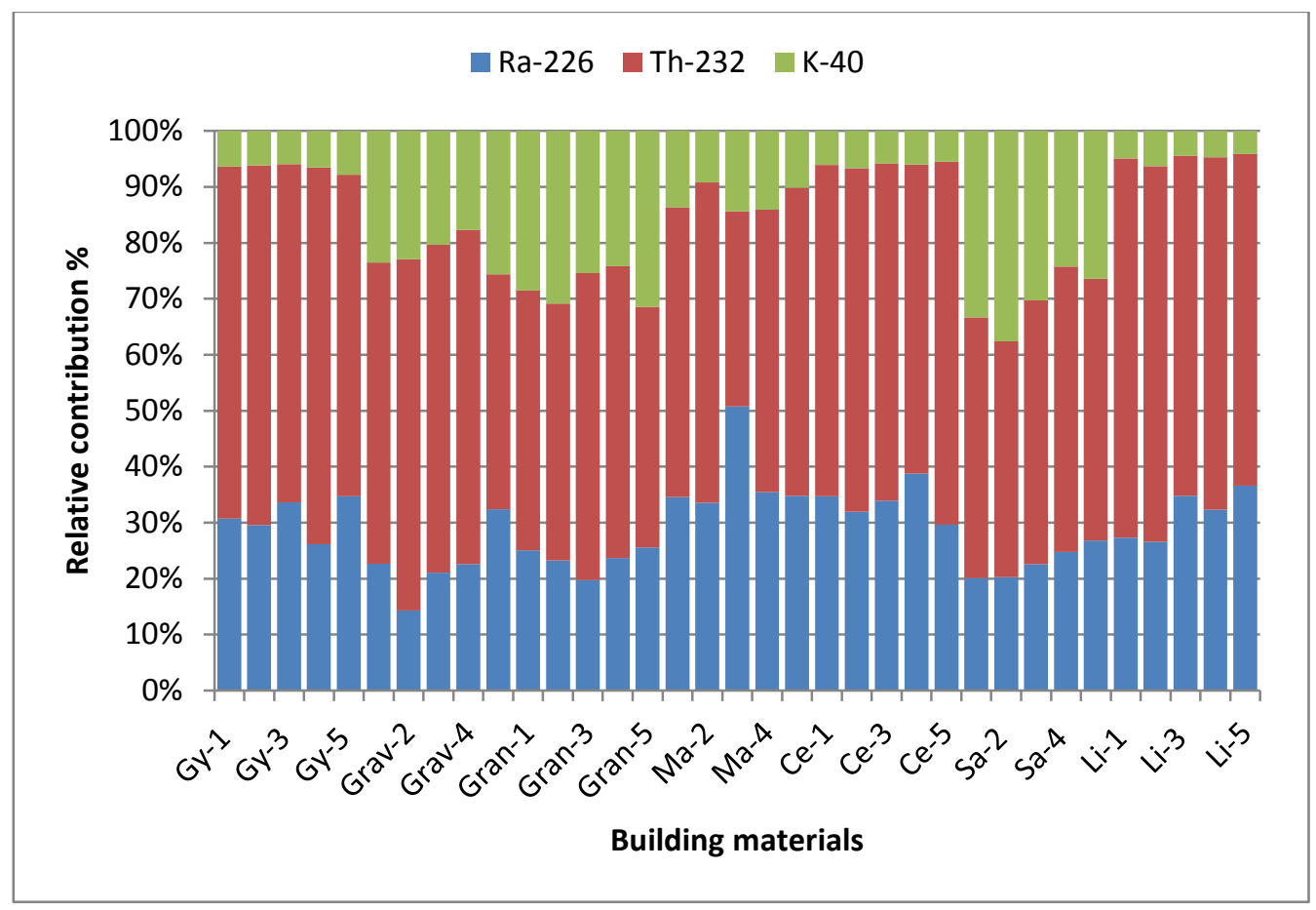

Figure 3. The Relative Concentration of ${ }^{226} \mathrm{Ra},{ }^{232} \mathrm{Th}$ and ${ }^{40} \mathrm{~K}$ to the $\mathrm{Ra}_{\mathrm{eq}}$ in Building Materials

Representative level index ranged from 0.29 to $0.59 \mathrm{~Bq} \mathrm{~kg}^{-1}$ with average value is 0.67 $\mathrm{Bq} \mathrm{kg}^{-1}$ (Table 2). The average value of RLI is $33 \%$ lower than the recommended safe limit $\leq 1$ (Table 3)[22]. Therefore, building materials present no radiation hazard and are not harmful to human beings. The average value of RLI is $33 \%$ lower than the recommended safe limit. 


\subsection{Activity Utilization Index (AUI)}

To facilitate the calculation of dose rates in air from different combinations of the three radionuclides in building materials samples and by applying the appropriate conversion factors, an activity utilization index (AUI) can be constructed, as given by the following expression [23]:

AUI $=\left(A_{R a} / 50\right) f_{U}+\left(A_{T h} / 50\right) f_{T h}+\left(A_{K} / 500\right) f_{K}$

The $f_{\mathrm{U}}(0.462), f_{\mathrm{Th}}(0.604)$ and $f_{\mathrm{K}}(0.041)$ are the fractional contributions to the total dose rate in air due to gamma radiation from the actual concentrations of these radionuclides. Table 2 represents the activity utilization index, which is ranged from 0.31 to 1.13 with average value is 0.72 . The average value of AUI is $64 \%$ lower than the recommended safe limit2 (Table 3), which correspond to an annual effective dose of $<0.3 \mathrm{mSv} \mathrm{y}^{-1}$ [24]. This indicates that, the building materials can be safely used for the construction of buildings.

Representative level index ranged from 0.29 to $0.59 \mathrm{~Bq} \mathrm{~kg}^{-1}$ with average value is 0.67 $\mathrm{Bq} \mathrm{kg}^{-1}$ (Table 2). The average value of RLI is 33\% lower than the recommended safe limit $\leq 1$ (Table 3) [22]. Therefore, building materials present no radiation hazard and are not harmful to human beings. The average value of RLI is $33 \%$ lower than the recommended safe limit

Table 4. Comparison of Activity Concentration and Radium Equivalent Activity with other Countries

\begin{tabular}{|c|c|c|c|c|c|c|}
\hline \multirow[t]{2}{*}{ Materials } & \multirow[t]{2}{*}{ Country } & \multicolumn{3}{|c|}{$\begin{array}{c}\text { Activity concentration } \\
\left(\mathrm{Bq} \mathrm{kg}^{-1}\right)\end{array}$} & \multirow[t]{2}{*}{$\begin{array}{c}\mathrm{Ra}_{\mathrm{eq}} \\
\left(\mathrm{Bq} \mathrm{kg}^{-1}\right)\end{array}$} & \multirow[t]{2}{*}{ References } \\
\hline & & ${ }^{226} \mathrm{Ra}$ & ${ }^{232} \mathrm{Th}$ & ${ }^{40} \mathrm{~K}$ & & \\
\hline \multirow[t]{4}{*}{ Gypsum } & Algeria & 50 & 21 & 275 & - & [10] Amrani and Tahtat 2001 \\
\hline & China & 64.7 & 48.7 & 161.3 & - & [11] Xinwei 2005 \\
\hline & India & 10 & 6 & 27 & - & [12] Kumar et al., 2003 \\
\hline & Saudi-Tabuk & 36.95 & 52.23 & 101.29 & 119.44 & Present study \\
\hline \multirow[t]{4}{*}{ Gravels } & Cuba & 20 & 13 & 134 & 48.91 & [13] Flores et al., 2008 \\
\hline & Greece & 11 & 12 & 140 & 38.9 & [14] Stoulos et al., 2003 \\
\hline & Turkey & 22.5 & 6.8 & 101.7 & 40.03 & [15] Mavi and Akkurt, 2010 \\
\hline & Saudi-Tabuk & 17.07 & 29.79 & 216.68 & 76.35 & Present study \\
\hline \multirow[t]{3}{*}{ Granite } & India & 82 & 112 & 125 & - & [12] Kumar et al., 2003 \\
\hline & Egypt & 59 & 70 & 1560 & - & [16] El Afifi et al.,(2006) \\
\hline & Saudi-Tabuk & 24.35 & 35.39 & 375.96 & 103.91 & Present study \\
\hline \multirow[t]{4}{*}{ Marble } & Algeria & 23 & 18 & 310 & - & [10] Amrani and Tahtat 2001 \\
\hline & Cameron & 8 & 0.35 & 19 & - & [17[ Ngachin et al.,(2007) \\
\hline & Egypt & 30 & 20 & 157 & - & [16] El Afifi et al.,(2006) \\
\hline & Saudi-Tabuk & 18.46 & 17.36 & 77.03 & 49.21 & Present study \\
\hline \multirow[t]{4}{*}{ Cement } & Turkey & 41 & 26 & 267 & 98 & [18] Turhan, 2008 \\
\hline & Egypt & 35.60 & 43.17 & 82.08 & 103 & [19] El-Taher et al., 2010 \\
\hline & Greece & 20 & 13 & 247 & 57.61 & [14] Stoulos et al., 2003 \\
\hline & Saudi-Tabuk & 42.66 & 52.90 & 97.73 & 125.83 & Present study \\
\hline \multirow[t]{4}{*}{ Sand } & Pakistan & 20 & 29 & 383 & 91 & [20] Faheem et al., 2008 \\
\hline & India & 40 & 55 & 590 & 164.1 & [21] Sonkawade et al., 2008 \\
\hline & Cameroon & 14 & 31 & 586 & 104.1 & [17] Ngachin et al., 2007 \\
\hline & Saudi-Tabuk & 17.51 & 24.78 & 289.77 & 75.25 & Present study \\
\hline
\end{tabular}




\subsection{Absorbed Gamma Dose Rate $(D)$}

The outdoor absorbed gamma dose rate $\left(D_{\text {out }}\right)$ at $1 \mathrm{~m}$ above the ground surface is assessed from the $\gamma$-radiation originating from ${ }^{226} \mathrm{Ra},{ }^{232} \mathrm{Th}$ and ${ }^{40} \mathrm{~K}$ supposed to be equally distributed in ground. For the conversion of $\gamma$-radiation originating from ${ }^{226} \mathrm{Ra},{ }^{232} \mathrm{Th}$ and ${ }^{40} \mathrm{~K}$, the factors of $0.436 \mathrm{nGy} \mathrm{h}{ }^{-1} \mathrm{~Bq}^{-1} \mathrm{~kg}^{-1}$ for ${ }^{226} \mathrm{Ra}, 0.599 \mathrm{nGy} \mathrm{h}{ }^{-1} \mathrm{~Bq}^{-1} \mathrm{~kg}^{-1}$ for ${ }^{232} \mathrm{Th}$ and $0.0417 \mathrm{nGy} \mathrm{h}^{-1} \mathrm{~Bq}^{-1} \mathrm{~kg}^{-1}$ for ${ }^{40} \mathrm{~K}$ were used for calculating the $\left(D_{\text {out }}\right)$. The conversion factors have been taken as means of those reported by Quindos [25]. The $\left(D_{\text {out }}\right)$ was calculated using the following equation by [7]:

$\mathrm{D}_{\text {out }}\left(\mathrm{nGy} \mathrm{h}^{-1}\right)=0.43 \mathrm{~A}_{\mathrm{Ra}}+0.666 \mathrm{~A}_{\mathrm{Th}}+0.047 \mathrm{~A}_{\mathrm{K}}$

The outdoor external doses $\left(D_{\text {out }}\right)$ due to the presence of ${ }^{226} \mathrm{Ra},{ }^{232} \mathrm{Th}$ and ${ }^{40} \mathrm{~K}$ in the building materials were calculated which range from 17.86 to $58.91 \mathrm{nGy} \mathrm{h}^{-1}$ (Table 2), with an average value of $41.75 \mathrm{nGy} \mathrm{h}^{-1}$. The average is 29.23 lower than the worlds' average of59 $\mathrm{nGy} \mathrm{h}^{-1}$ [7]. The $\gamma$-ray dose $\left(D_{\text {in }}\right)$ imparted by ${ }^{226} \mathrm{Ra},{ }^{232} \mathrm{Th}$ and ${ }^{40} \mathrm{~K}$ present in the indoor is calculated by converting the absorbed dose rate into effective dose using the three conversion factors; $0.92 \mathrm{~Gy} \mathrm{~h}^{-1}$ per Bq kg ${ }^{-1}$ for ${ }^{226} \mathrm{Ra}, 1.1 \mathrm{nGy} \mathrm{h}^{-1}$ per Bq kg ${ }^{-1}$ for ${ }^{232} \mathrm{Th}$ and $0.081 \mathrm{nGy} \mathrm{h}^{-1}$ per Bq kg${ }^{-1}$ for ${ }^{40} \mathrm{~K}$. By utilizing the above mentioned conversion factors following equation was used to calculate the $\left(D_{\text {in }}\right)$ [7].

$\mathrm{D}_{\text {in }}\left(\mathrm{nGy} \mathrm{h}^{-1}\right)=0.92 \mathrm{~A}_{\mathrm{Ra}}+1.1 \mathrm{~A}_{\mathrm{Th}}+0.081 \mathrm{~A}_{\mathrm{K}}$

The calculated indoor gamma dose rates for 35 samples are shown in Table 2. The calculated minimum and maxim values are 34.78 and114.56, respectively, with an average of $80.73 \mathrm{nGyh}^{-1}$ (Table 3), which is $3.89 \%$ lower than the world's average of $84 \mathrm{nGy} \mathrm{h}^{-1}$ [7]. From calculated indoor gamma dose rates values, it is observed that, the 54.28\% (19 samples) exceed the worldwide mean value. Building materials with much higher $D_{\text {in }}$ values may cause radiation hazards and hence must be avoided for construction purposes. As shown in Figure 4 , the ${ }^{232} \mathrm{Th}$ is the main contributor to $D_{\text {in }}$ in all samples, except in marble (Ma-3) the main contributor to $D_{\text {in }}$ is ${ }^{226} \mathrm{Ra}$ and in sand (Sa-2) the main contributor to $D_{\text {in }}$ is ${ }^{40} \mathrm{~K}$. The sum of the relative contribution of ${ }^{226} \mathrm{Ra}$ and ${ }^{232} \mathrm{Th}$ to $\mathrm{D}_{\text {in }}$ is $56.34-94.7 \%$ in all analyzed building materials.

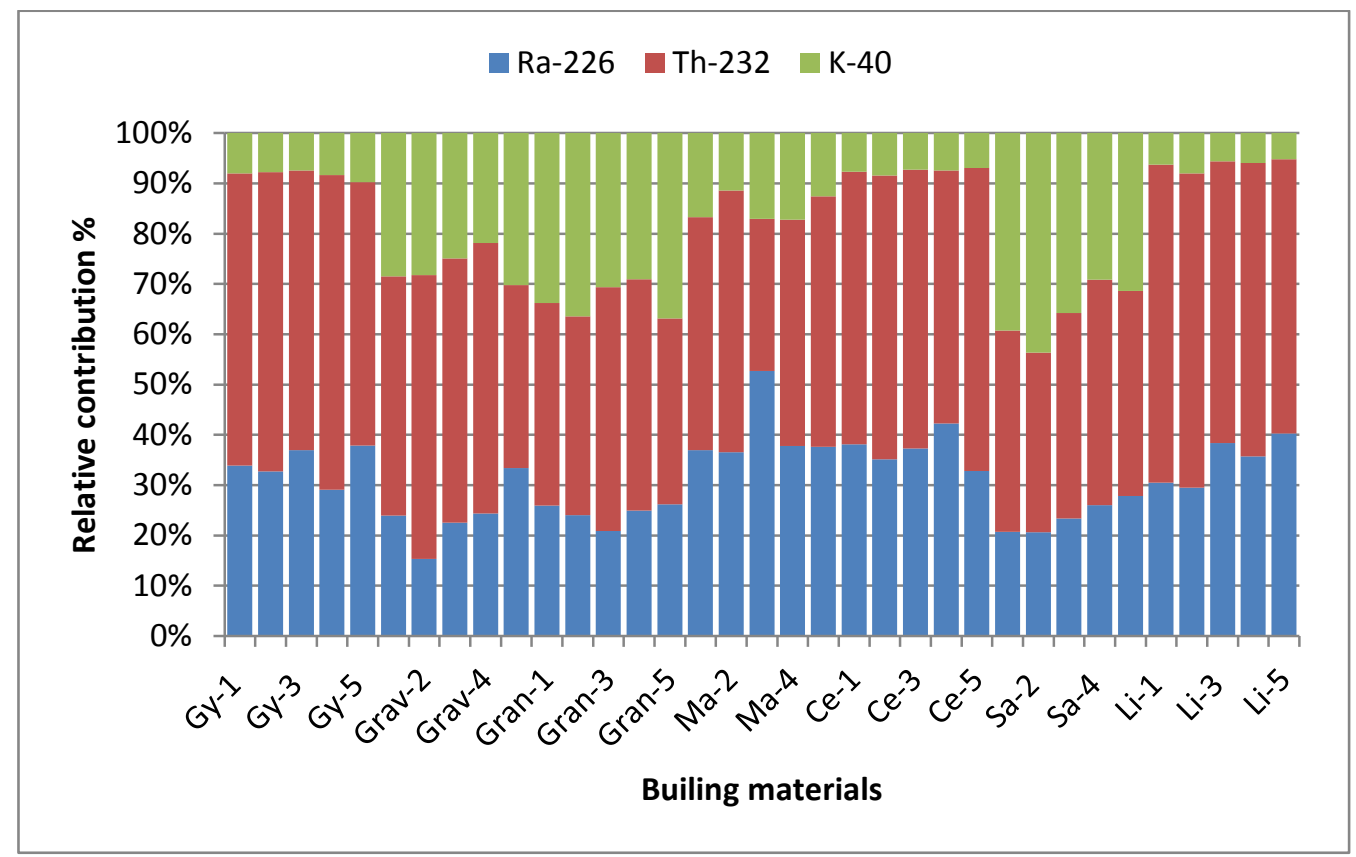

Figure 4. The Relative Concentration of ${ }^{226} \mathrm{Ra},{ }^{232} \mathrm{Th}$ and ${ }^{40} \mathrm{~K}$ to the $\mathrm{D}_{\text {in }}$ in Building Materials 


\subsection{Annual Effective Dose $(E)$}

The annual effective dose is of two types. The annual indoor effective dose $\left(E_{i n}\right)$ and annual outdoor effective dose $\left(E_{\text {out }}\right)$.The $\left(E_{\text {out }}\right)$ is estimated from the dose rate $\left(D_{\text {out }}\right)$, time of stay in the outdoor or occupancy factor is $20 \%$ of $8760 \mathrm{~h}$ in a year and the conversion factor is $0.7 \mathrm{~Sv} \mathrm{~Gy}{ }^{-1}$ to convert the absorbed dose in air to effective dose. During the present study, the $\left(E_{\text {out }}\right)$ was calculated using the following equation [7]:

$$
\mathrm{E}_{\text {out }}\left(\mathrm{mSv} \mathrm{y}^{-1}\right)=\mathrm{D}_{\text {out }} \times 8766 \times 0.2 \times 10^{-6}
$$

The annual outdoor effective dose values for building materials are listed in Table 2 . The calculated $D_{\text {in }}$ values are between 0.02 and $0.07 \mathrm{mSv} \mathrm{y}^{-1}$ with an average value of $0.05 \mathrm{mSv} \mathrm{y}^{-1}$ (Table 3), which is $28.57 \%$ lower than the world's average of $0.07 \mathrm{mSv} \mathrm{y}^{-1}$ [7].

The annual indoor effective dose $\left(E_{\text {in }}\right)$ is the dose which a person receives in the indoor environment. The $\left(E_{\text {in }}\right)$ depends on the indoor external $\operatorname{dose}\left(D_{\text {in }}\right)$ that is the $\gamma$-ray dose within the buildings, dose conversion factor $\left(\mathrm{CFthat}\right.$ is $\left.0.7 \mathrm{~Sv} \mathrm{~Gy}^{-1}\right)$ and the time of stay in the indoor is $80 \%$ of the in a year. The annual indoor effective dose $\left(E_{\text {in }}\right)$ was calculated as per equations given below [7]:

$$
\mathrm{E}_{\text {in }}\left(\mathrm{mSv} \mathrm{y}^{-1}\right)=\mathrm{D}_{\text {out }} \times 8766 \times 0.8 \times 10^{-6}
$$

The $\left(E_{\text {in }}\right)$ calculated for the building materials used in Tabuk, Saudi Arabia are given in Table 2. It ranges from 0.17 to 0.56 with an average of $0.39 \mathrm{mSv} \mathrm{y}^{-1}$ which is $4.87 \%$ lower than the world's average of $0.41 \mathrm{mSv} \mathrm{y}^{-1}$. From calculated annual indoor effective dose $\left(E_{\text {in }}\right)$ values, it is observed that, the $54.29 \%$ (19 samples) exceed the worldwide mean value.

\subsection{Alpha index $\left(I_{a}\right)$}

From the radon inhalation, which originates from building materials, the excess alpha radiation $\left(\mathrm{nGy} \mathrm{h}^{-1}\right)$ is calculated using the following relation [26]:

$\mathrm{I}_{\alpha}=\mathrm{A}_{\mathrm{Ra}} / 200$

When the ${ }^{226} \mathrm{Ra}$ activity concentration $\left(A_{\mathrm{Ra}}\right)$ of building material exceeds the value of 200 $\mathrm{Bqkg}^{-1}$, it is possible that the radon exhalation from this material could cause indoor radon concentration exceeding $200 \mathrm{Bqm}^{-3}$. The calculated values of $\left(I_{\alpha}\right)$ are listed in Table 2. The recommended exemption level and recommended upper level for the ${ }^{226} \mathrm{Ra}$ activity concentrations in building materials are $100 \mathrm{~Bq} \mathrm{~kg}^{-1}$ and $200 \mathrm{~Bq} \mathrm{~kg}^{-1}$, respectively, in building materials as suggested by the Radiation Protection Authorities in Denmark, Finland, Iceland, Norway and Sweden [27]. The calculated $I_{\alpha}$ values are between 0.06 and 0.26 with an average value of 0.13 , which is $87 \%$ less than the world recommended mean value, see Table 3 .

\subsection{Gamma Index $\left(I_{\gamma}\right)$}

In order to assess whether the safety requirements for building materials are being fulfilled, a gamma index $I_{\gamma}$ is calculated as proposed by the European Commission [28]:

$\mathrm{I}_{\gamma}=\left(\mathrm{A}_{\mathrm{Ra}} / 300\right)+\left(\mathrm{A}_{\mathrm{Th}} / 200\right)+\left(\mathrm{A}_{\mathrm{K}} / 3000\right)$

$I_{\gamma} \leq 2$ correspond to an absorbed gamma dose rate of $0.3 \mathrm{mSv} \mathrm{y}^{-1}$, whereas $2<\gamma \leq 6$ corresponds to an absorbed gamma dose rate of $1 \mathrm{mSv} \mathrm{y}^{-1}$ [28]. Thus, the activity concentration index should be used only as a screening tool for identifying materials that might be of concern when used as construction materials; although materials with $I_{\gamma}>6$ should be avoided, these values correspond to dose rates higher than $1 \mathrm{mSv} \mathrm{y}^{-1}$, which is the highest dose rate value recommended for the population [2].The gamma index $I_{\gamma}$ for 
the building materials varies between 0.14 and 0.48 , as presented in Table 2 . The average gamma index is $67 \%$ less than the recommended value (Table 3 ).

\subsection{Radiation Hazard Indices}

The external hazard index $H_{\mathrm{ex}}$ can be calculated by the following equation [9]:

$\mathrm{H}_{\mathrm{ex}}=\left(\mathrm{A}_{\mathrm{Ra}} / 370\right)+\left(\mathrm{A}_{\mathrm{Th}} / 259\right)+\left(\mathrm{A}_{\mathrm{K}} / 4810\right) \leq 1$

The value of this index must be less than the unity in order to keep the radiation hazard to be insignificant. The maximum value of $H_{\mathrm{ex}}$ equal to unity corresponds to the upper limit of $R a_{\mathrm{eq}}\left(370 \mathrm{~Bq} \mathrm{~kg} \mathrm{~kg}^{-1}\right)$. The calculated external hazard index values are presented in Table 2. The calculated external hazard index values are between 0.11 and 0.37 with average value of 0.25 , which is $75 \%$ less than recommended value (Table 3 ). As shown in Figure 5, the ${ }^{232} \mathrm{Th}$ is the main contributor to $H_{\mathrm{ex}}$ in all samples, except in marble (Ma-3) the main contributor to $H_{\mathrm{ex}}$ is ${ }^{226} \mathrm{Ra}$. The sum of the relative contribution of ${ }^{226} \mathrm{Ra}$ and ${ }^{232} \mathrm{Th}$ to $H_{\text {ex }}$ is $62.40-95.84 \%$ in all analyzed building materials.

In addition to the external hazard index, radon and its short lived progeny are also hazardous to the respiratory organs. The internal exposure to radon and its daughter progenies is quantified by the internal hazard index $H_{\text {in }}$ [7], which is given by the equation:

$\left.\mathrm{H}_{\mathrm{in}}=\left(\mathrm{A}_{\mathrm{Ra}} / 185\right)+\left(\mathrm{A}_{\mathrm{Th}} / 259\right)+/ 9 \mathrm{~A}_{\mathrm{K}} / 4810\right) \leq 1$

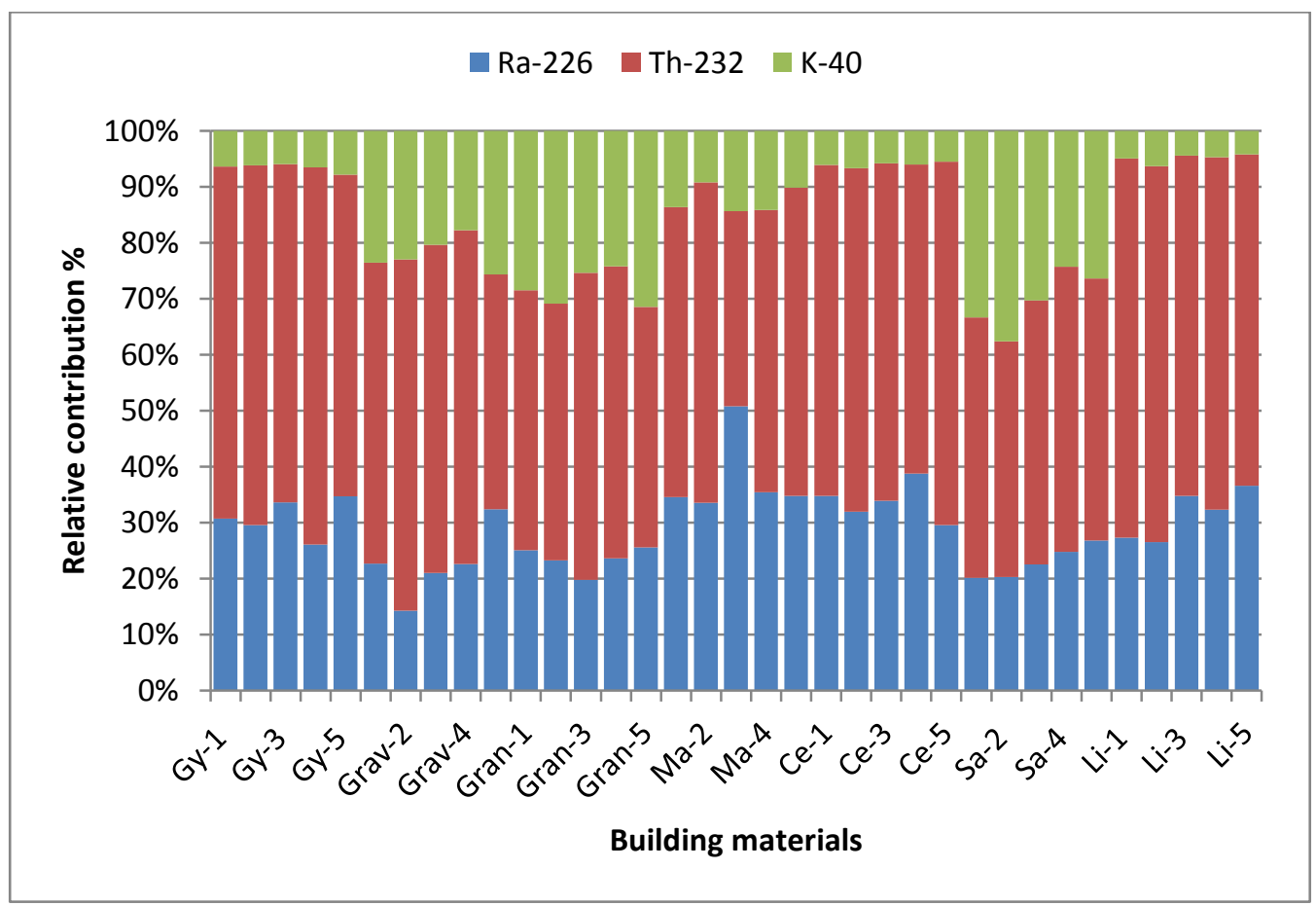

Figure 5. The Elative Concentration of ${ }^{226} \mathrm{Ra},{ }^{232} \mathrm{Th}$ and ${ }^{40} \mathrm{~K}$ to the $\mathrm{H}_{\mathrm{ex}}$ in Building Materials

For safety measurements in the use of materials for building constructions, it should note that internal hazard index is $\leq 1$. Table 2 presents the calculated values of $H_{\text {in }}$. The calculated internal hazard index values are between 0.15 and 0.51 with average value of 0.32 , which is $68 \%$ less than recommended value (Table 3 ). 


\subsection{Excessive Lifetime Cancer Risk (ELCR)}

Based upon calculated values of annual effective dose excess lifetime cancer risk (ELCR) was calculated using the following equation;

$\mathrm{ELCR}_{\text {out }}=\mathrm{E}_{\text {out }} \times \mathrm{LE} \times \mathrm{RF}$

$\mathrm{ELCR}_{\text {in }}=\mathrm{E}_{\text {in }} \times \mathrm{LE} \times \mathrm{RF}$

Where $\left(E_{\text {out }}\right)$ and $\left(E_{\text {in }}\right)$ are the annual effective doses, LE life expectancy (70 years) and $\mathrm{RF}\left(\mathrm{Sv}^{-1}\right)$ is fatal risk factor per Sievert. For stochastic effects, ICRP 60 uses values of 0.05 for the public [30].The calculated external excess lifetime cancer risk $\left(E L C R_{\text {out }}\right)$ and internal excess lifetime cancer risk $\left(E L C R_{\text {in }}\right)$ are presented in Table 2 . The calculated external excess lifetime cancer risk $\left(E L C R_{\text {out }}\right)$ values are between $0.08 \times 10^{-3}$ and $0.25 \times 10^{-3}$ with an average value of $0.18 \times 10^{-3}$ (Table 3 ), which is 37.93 less than the upper limit $0.29 \times 10^{-3}[29]$. The calculated internal excess lifetime cancer risk $\left(E L C R_{\text {in }}\right)$ values are between $0.6 \times 10^{-3}$ and $2 \times 10^{-3}$ with an average value of $1.4 \times 10^{-3}$ (Table 3 ), which is 20.68 higher than the upper limit $1.16 \times 10^{-3}$. It is interesting to note that $71.42 \%$ ( 25 samples) of the internal excess lifetime cancer risk was greater than the upper recommended value. Building materials with much higher $E L C R_{\text {in }}$ values may cause radiation hazards and hence must be avoided for construction purposes.

\subsection{Annual Gonadal Dose Equivalent (AGDE)}

It is a measure of the genetic significance of the yearly dose equivalent received by the population's reproductive organs (gonads) [2]. In the same context, the activity bone marrow and the bone surface cells are considered as the organs of interest by [30].Therefore, the annual gonadal dose equivalent (AGDE) $\left(\mu \mathrm{Sv} \mathrm{y}^{-1}\right)$ for people living inside a building due to the specific activities of ${ }^{226} \mathrm{Ra},{ }^{232} \mathrm{Th}$ and ${ }^{40} \mathrm{Kpresent}$ in building materials is calculating using the following formula [26]:

$\mathrm{AGDE}=3.09 \mathrm{~A}_{\mathrm{Ra}}+4.18 \mathrm{~A}_{\mathrm{Th}}+0.314 \mathrm{~A}_{\mathrm{K}}$

The obtained values of annual gonadal dose equivalent are presented in Table 2 . The values ranged from 126.92 to $415.65 \mu \mathrm{Sv} \mathrm{y}{ }^{-1}$ with an average value of $296.7 \mu \mathrm{Sv} \mathrm{y}{ }^{-1}$, which is $1.1 \%$ less than the world recommended value (Table 3) [31]. From calculated indoor gamma dose rates values, it is observed that, the 54.28\% (19 samples) exceed the worldwide mean value which is between 316.68 and $415.65 \mu \mathrm{Sv} \mathrm{y}^{-1}$.

\section{Basic Statistical}

The results of the statistical parameters are presented in Table 5. In probability theory and statistics, skewnessis a measure of the asymmetry of the probability distribution of real valued random variable. Skewness has benefits in many areas. Many models assume normal distribution, i.e., data are symmetric about the mean. The normal distribution has a skewness of zero. However, in reality, data points may not be perfectly symmetric. Therefore, an understanding of the skewness of the dataset indicates whether deviations from the mean are going to be positive or negative. Skewness characterizes the degree of asymmetry of a distribution around its mean [32]. Positive skewness indicates a distribution with an asymmetric tail extending towards values that are more positive. Negative skewness indicates a distribution with an asymmetric tail extending towards valuesthat is more negative. Lower skewness value form generally normal distributions. Table 5 presents that, the ${ }^{226} \mathrm{Ra}$ and ${ }^{40} \mathrm{~K}$ radionuclides have the positive skewness values, and the ${ }^{232}$ Thradionuclide has the negative skewness value. These values are lower skewness, which indicate the asymmetric nature.

Kurtosis is a measure of the peakedness of the probability distribution of a real valued random variable. It characterizes the relative peakedness or flatness of a distribution 
compared with the normal distribution. Positive Kurtosis indicates a relatively peaked distribution. Negative kurtosis indicates a relatively flat distribution. Higher kurtosis means more of the variance is a result of infrequent extreme deviations, as opposed to frequent modestly sized deviations [33]. In the present study all the radionuclides have negative kurtosis values (Table 5) which indicates a flat distribution.

Table 5. Descriptive Statistics of Collected Building Materials

\begin{tabular}{lccc}
\hline Variables & ${ }^{\mathbf{2 2 6}} \mathbf{R a}$ & ${ }^{{ }^{232}} \mathbf{T h}$ & ${ }^{\mathbf{4 0}} \mathbf{K}$ \\
\hline Range & 41.47 & 48.73 & 333.76 \\
Variance & 127.319 & 210.762 & $1.297 \mathrm{E} 4$ \\
Skewness & 0.491 & -0.061 & 0.722 \\
Kurtosis & -0.847 & -1.244 & -1.009 \\
\hline
\end{tabular}

\subsection{Histograms}

A histogram is a graphical representation of the distribution of data. It is an estimate of the probability distribution of a continuous variable. A histogram is a representation of tabulated frequencies, shown as adjacent rectangles, erected over discrete intervals (bins), with an area equal to the frequency of the observations in the interval. The height of a rectangle is also equal to the frequency density of the interval, i.e., the frequency divided by the width of the interval. The total area of the histogram is equal to the number of data. A histogram may also be normalized displaying relative frequencies. The rectangles of a histogram are drawn so that they touch each other to indicate that the original variable is continuous [2]. The frequency distributions of all the radionuclides were analyzed, and the histograms are given in Figures $6-8$. Graphs for ${ }^{226} \mathrm{Ra},{ }^{232} \mathrm{Th}$ and ${ }^{40} \mathrm{~K}$ show that these radionuclides demonstrate a normal (bell-shaped) distribution.

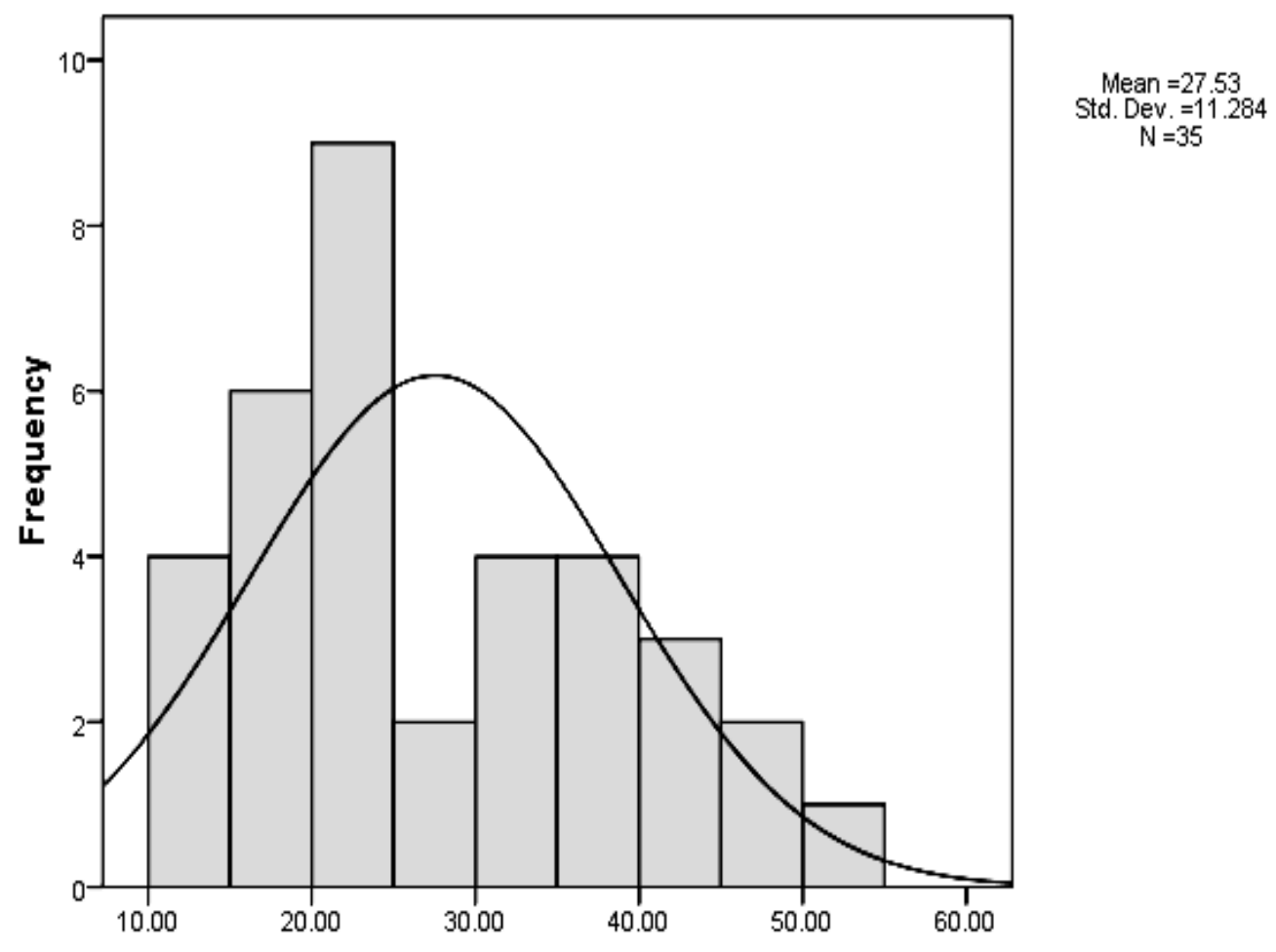

Figure 6. The Frequency Distribution of the Activity of ${ }^{226} \mathrm{Ra}$ 


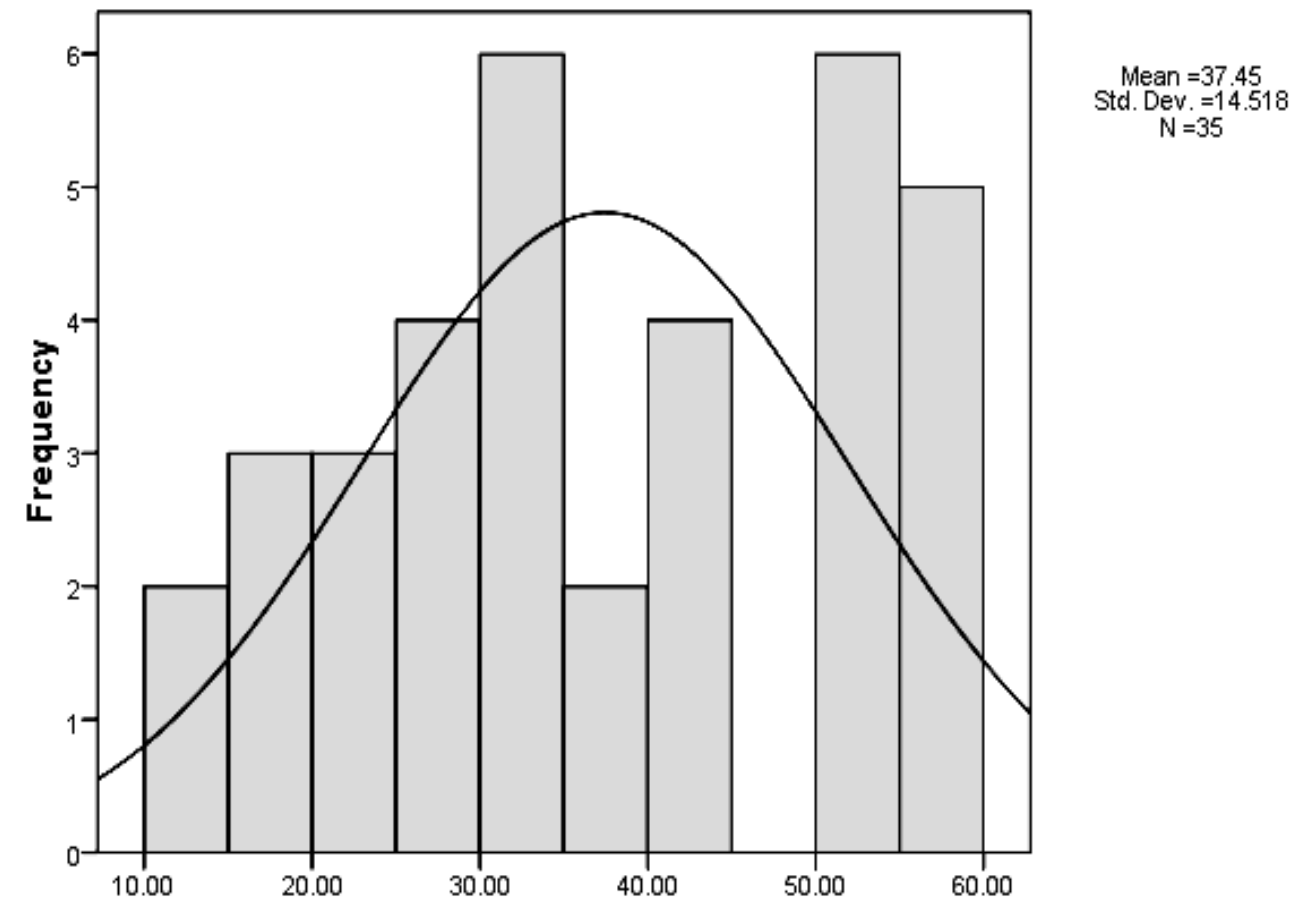

Figure 7.The Frequency Distribution of the Activity of ${ }^{232} \mathrm{Th}$

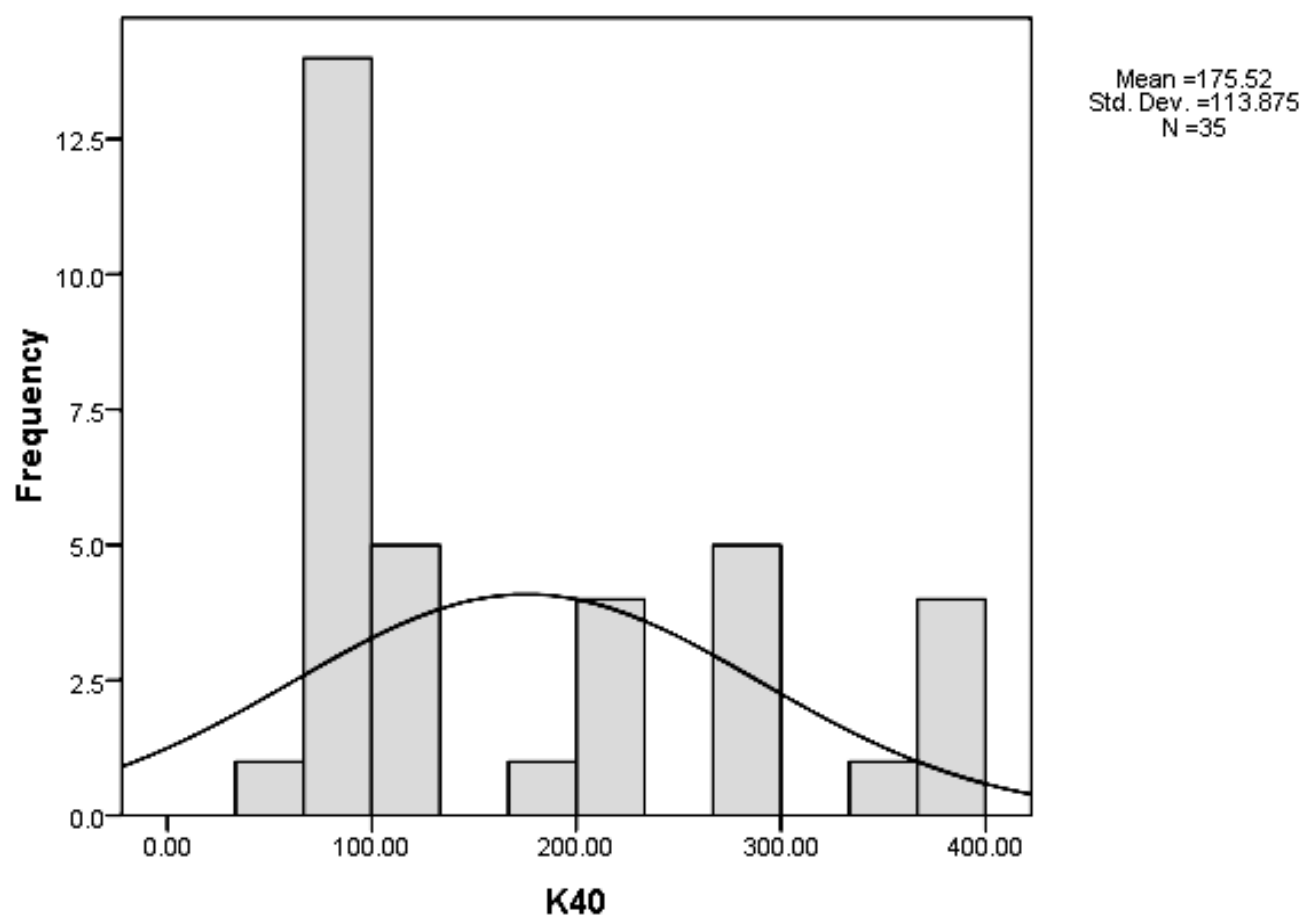

Figure 8. The Frequency Distribution of the Activity of ${ }^{40} \mathrm{~K}$

\subsection{Principal Component Analysis (PCA)}

Factor analysis was carried out on the data set (17 variables as in the above analyses) to assess the relationship as per the procedure given in [23]. The rotated factor 1 and factor 2 values are reported in Table 6 . Factor analysis yielded two factors with eigen value $<1$, explaining $98.257 \%$ of the total variance. From rotate space of component-1 (PC1) and component-2 (PC2), the first factor accounted for $85.489 \%$ of the total variance and 
mainly characterized by high positive loading of concentrations of ${ }^{226} \mathrm{Ra},{ }^{232} \mathrm{Th}$. Factor-2 accounted for $12.768 \%$ of the total variance, which mainly consists of positive loading of $^{226}$ Ra.Figure 9 shows the rotated factor loadings of radiological parameters.

\subsection{Cluster Analysis}

To confirm the existing correlation between the variables, cluster analysis (CA) is carried out. It is a multivariate technique, whose primary purpose is to classify the objects of the system into categories or clusters based on their similarities, and the objective is to find an optimal grouping for which the observations or objects within each cluster are similar, but the clusters are dissimilar from each other. Similarity is a measure of distance between clusters relative to the largest distance between any two individual variables. The $100 \%$ similarity means that the clusters were zero distance apart in their sample measurements, where as similarity of $0 \%$ means the cluster areas are as disparate as the least similar region. Cluster analysis was carried out through axes to identify similar characteristics among natural radioisotopes and radiological parameters in the building materials [2].

In cluster analysis, the average linkage method along with correlation coefficient distance was applied and the derived dendrogram was shown in Figure 10.In this dendrogram, all 17 parameters and three radionuclides were grouped into three statistically significant clusters. Cluster-I consists of RLI, $D_{\text {out }}, D_{\text {in }}, E_{\text {in }}$, ADGE, $I_{\gamma}$, $E L C R_{\text {out }}, E L C R_{\text {in }}, R a_{\text {eq }}, H_{\text {ex }}$ and $E_{\text {out }}$.Cluster-II consists of AUI, $H_{\text {in }},{ }^{232} \mathrm{Th},{ }^{226} \mathrm{Ra}$ and Ia. Cluster-III separately accounted for ${ }^{40} \mathrm{~K}$. From this cluster analysis, internal hazard index in the study area are due to the concentration of ${ }^{226} \mathrm{Ra}$ and ${ }^{232} \mathrm{Th}$. Cluster-III suggests that ${ }^{40} \mathrm{~K}$ does not contribute to any radiological parameters in the building materials.

Table 6.Rotated Factor Loading of the Variables

\begin{tabular}{|c|c|c|}
\hline \multirow[t]{2}{*}{ Variables } & \multicolumn{2}{|c|}{ Component } \\
\hline & PCA1 & PCA2 \\
\hline${ }^{226} \mathrm{Ra}$ & 0.784 & 0.561 \\
\hline${ }^{232} \mathrm{Th}$ & 0.891 & 0.366 \\
\hline${ }^{40} \mathrm{~K}$ & 0.067 & -0.984 \\
\hline$R a_{\mathrm{eq}}$ & 0.982 & 0.186 \\
\hline RLI & 0.993 & 0.108 \\
\hline AUI & 0.902 & 0.427 \\
\hline$D_{\text {out }}$ & 0.994 & 0.106 \\
\hline$D_{\text {in }}$ & 0.994 & 0.112 \\
\hline$E_{\text {out }}$ & 0.980 & 0.079 \\
\hline$E_{\text {in }}$ & 0.993 & 0.113 \\
\hline$I_{\alpha}$ & 0.783 & 0.563 \\
\hline$I_{\gamma}$ & 0.994 & 0.103 \\
\hline$H_{\mathrm{ex}}$ & 0.984 & 0.173 \\
\hline$H_{\text {in }}$ & 0.952 & 0.302 \\
\hline$E L C R_{\text {out }}$ & 0.992 & 0.117 \\
\hline$E L C R_{\text {in }}$ & 0.990 & 0.120 \\
\hline ADGE & 0.997 & 0.078 \\
\hline Variance explained in $\%$ & 85.489 & 12.768 \\
\hline
\end{tabular}




\subsection{Pearson's Correlation Coefficient Analysis}

Correlation analysis has been carried out as a bivariate statistics in order to determine the mutual relationships and strength of association between pairs of variables through calculation of the linear Pearson correlation coefficient. Table 7 presents that, the results for Pearson correlation coefficients between all the studied radioactive variables for building materials. High good positive correlation co-efficient was observed between ${ }^{232} \mathrm{Th}$ and ${ }^{226} \mathrm{Ra}$ because radium and thorium decay series occur combined together in nature [34].But very weak negative correlation co-efficient was observed between ${ }^{40} \mathrm{~K}$ and ${ }^{226} \mathrm{Ra},{ }^{232} \mathrm{Th}$ since ${ }^{40} \mathrm{~K}$ origins are in different decay series. Radiological parameters (radium equivalent, representative level Index, activity utilization index, outdoor absorbed dose rate, indoor absorbed dose rate, outdoor annual effective dose, indoor annual effective dose, external radiation hazard, internal radiation hazard, outdoor excess lifetime cancer risk, indoor excess lifetime cancer risk and Annual gonadal dose equivalent)have high good positive correlation coefficients $w_{i t h}{ }^{226} \mathrm{Ra}$ and ${ }^{232} \mathrm{Th}$, while they are have a weak negative correlation with ${ }^{40} \mathrm{~K}$. This implies that there is a very strong relationship between the radionuclides of ${ }^{226} \mathrm{Ra} \mathrm{and}^{232} \mathrm{Th}$ in building materials and radiological parameters.

\section{Conclusions}

The ${ }^{226} \mathrm{Ra},{ }^{232} \mathrm{Th}$ and ${ }^{40} \mathrm{~K}$ content, Radium equivalent $\left(R a_{\mathrm{eq}}\right)$, representative level Index (RLI), activity utilization index (AUI), outdoor absorbed dose rate $\left(D_{\text {out }}\right)$, indoor absorbed dose rate $\left(D_{\text {in }}\right)$, outdoor annual effective dose $\left(E_{\text {out }}\right)$, indoor annual effective dose $\left(E_{\text {in }}\right)$, external radiation hazard $\left(H_{\mathrm{ex}}\right)$, internal radiation hazard $\left(H_{\mathrm{in}}\right)$, outdoor excess lifetime cancer risk $\left(E L C R_{\text {out }}\right)$,indoor excess lifetime cancer risk $\left(E L C R_{\text {in }}\right)$ and Annual gonadal dose equivalent (AGDE)of some building materials commonly used in Tabuk, KSA, were determined. The values obtained in the study are within the recommended safety limits, demonstrating that these building materials do not pose any significant radiation hazard; thus, the use of these materials in the construction of dwellings can be considered safe for the inhabitants.

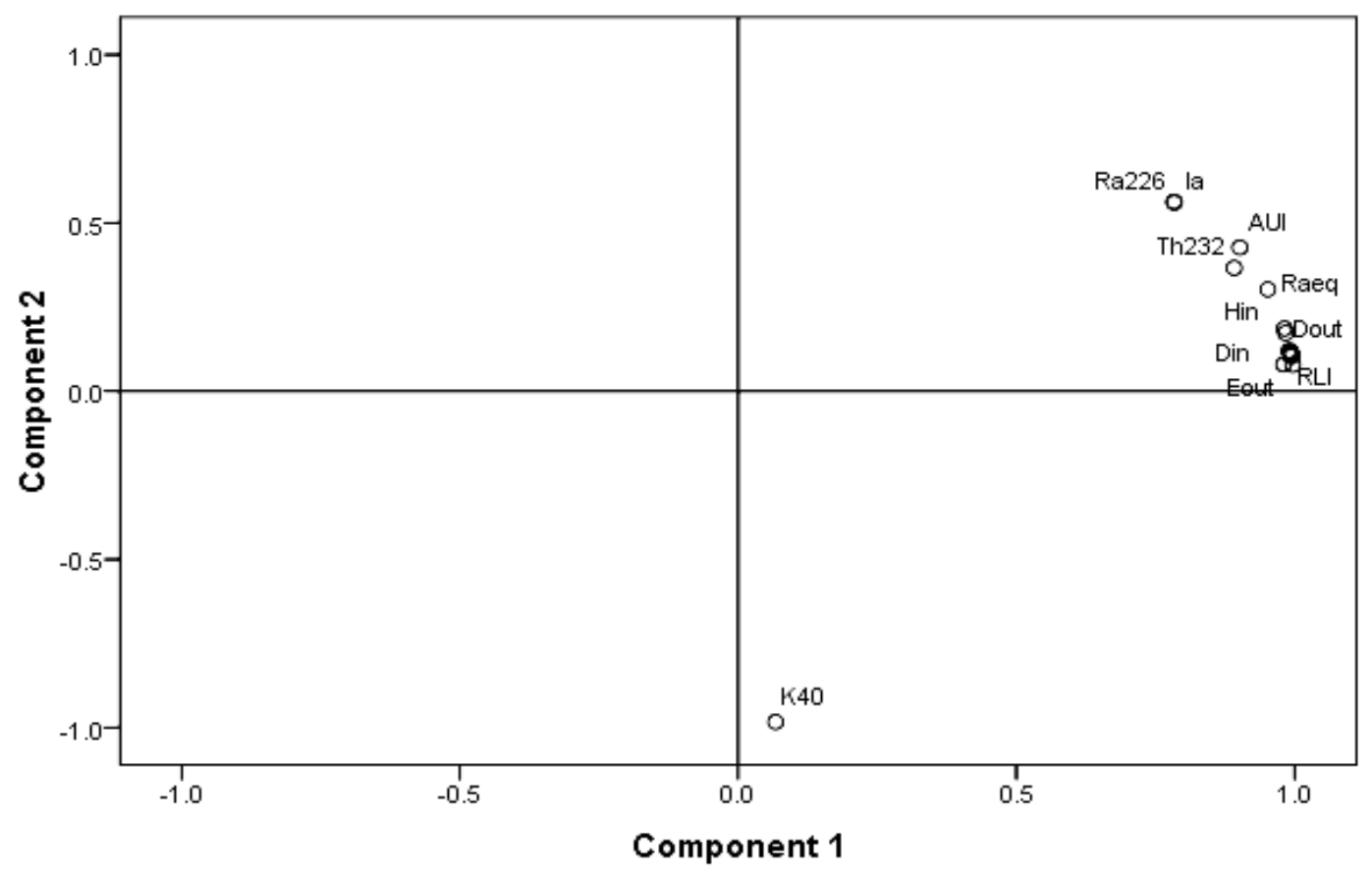

Figure 9. Graphical Representation of Factors 1 and 2 


\section{Dendrogram using Average Linkage}

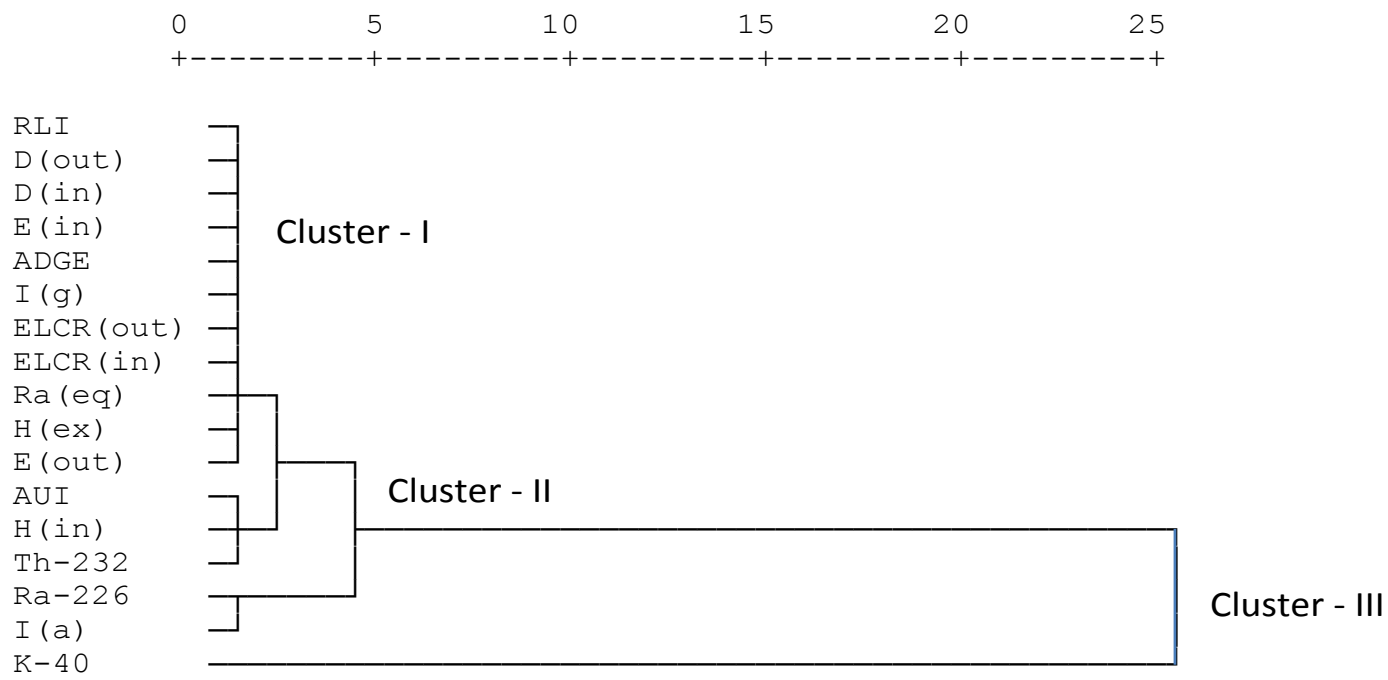

Figure 10. Dendrogram Shows the Clustering of Radionuclides

Table 7. Pearson Correlation Matrix among the Variables

\begin{tabular}{|c|c|c|c|c|c|c|c|c|c|c|c|c|c|c|c|c|c|c|}
\hline & ${ }^{26} \mathrm{Ra}$ & Th & tK & $\mathrm{Ra}_{\mathrm{mp}}$ & RLI & $\mathrm{AUI}$ & $D_{\text {out }}$ & $D_{\text {in }}$ & $E_{\text {out }}$ & $E_{\text {in }}$ & $I_{0}$ & 1 & & $H_{\mathrm{eg}}$ & $H_{i}$ & ${ } E L C R_{v e}$ & $\mathbb{E L C R}$ & A $A D G E$ \\
\hline${ }_{R A}$ & 1 & & & & & & & & & & & & & & & & & \\
\hline${ }^{25} \mathrm{Th}$ & 0.833 & 1 & & & & & & & & & & & & & & & & \\
\hline${ }^{40} \mathrm{~K}$ & -0.455 & .0 .344 & 1 & & & & & & & & & & & & & & & \\
\hline $\mathrm{Ra}_{\mathrm{Bg}}$ & 0.864 & 0.954 & -0.123 & 1 & & & & & & & & & & & & & & \\
\hline RLI & 0.831 & 0.934 & $\cdot 0.045$ & 0.997 & 1 & & & & & & & & & & & & & \\
\hline AUI & 0.929 & 0.978 & .0370 & 0.967 & 0.94 & 1 & & & & & & & & & & & & \\
\hline$D_{\text {out }}$ & 0.834 & 0.930 & .0 .040 & 0.997 & 1 & 0.94 & 1 & & & & & & & & & & & \\
\hline$D_{\text {in }}$ & 0.842 & 0.926 & -0.043 & 0.996 & 0.999 & 0.94 & 41 & 1 & & & & & & & & & & \\
\hline$E_{\text {out }}$ & 0.805 & 0.009 & .0 .19 & 0.976 & 0.980 & 0.918 & 0.981 & 0.981 & 1 & & & & & & & & & \\
\hline$E_{\text {in }}$ & 0.841 & 0.928 & $\cdot 0.045$ & 0.996 & 0.999 & 0.944 & 41 & 1 & 0.98 & $\begin{array}{ll}0 & 1\end{array}$ & & & & & & & & \\
\hline$I_{0}$ & 0.999 & 0.834 & $\begin{array}{r}-0.457 \\
\end{array}$ & 0.864 & 0.831 & 0.929 & 0.833 & 0.842 & 0.80 & $\begin{array}{lll}5 & 0.841\end{array}$ & 1 & & & & & & & \\
\hline I & 0.828 & 0.932 & .0 .040 & 0.996 & 0.999 & 0.942 & 1 & 0.999 & 0.98 & 20.999 & 0.827 & 71 & 1 & & & & & \\
\hline$H_{\mathrm{gx}}$ & 0.861 & 0.948 & .0108 & 0.999 & 0.997 & 0.963 & 0.997 & 0.997 & 0.97 & $\begin{array}{ll}7 & 0.997\end{array}$ & 0.860 & 00.9 & 996 & 1 & & & & \\
\hline$H_{\text {in }}$ & 0.928 & 0.947 & .0226 & 0.989 & 0.977 & 0.984 & +0.977 & 0.980 & 0.95 & $5 \quad 0.979$ & 0.927 & 70.9 & 975 & 0.987 & 1 & & & \\
\hline$E L C R_{\text {ot }}$ & 0.838 & 0.932 & -0.051 & 0.996 & 0.999 & 0.94 & 0.999 & 0.999 & 0.97 & 90.998 & 0.838 & 80.9 & 998 & 0.997 & 0.978 & 1 & & \\
\hline$E L C R_{i}$ & 0.853 & 0.918 & -0.046 & 0.994 & 0.996 & 0.942 & 0.997 & 0.998 & 0.97 & $\begin{array}{ll}3 & 0.997\end{array}$ & 0.852 & 20.9 & 995 & 0.995 & 0.981 & 0.996 & 1 & \\
\hline ADGE & 0.822 & 0.920 & .0 .012 & 0.994 & 0.999 & 0.933 & 1 & 0.999 & 0.98 & 10.999 & 0.822 & 20.9 & 999 & 0.995 & 0.972 & 0.998 & 0.997 & 1 \\
\hline
\end{tabular}

\section{Acknowledgments}

This work was carried out using the nuclear analytical facilities at the Physics Department, Faculty of Sciences, Al-Azhar University, Assiut, Egypt. 


\section{References}

[1] L. Xinwei, Y. Guang and R. Chunhui, "Radiation Physics and Chemistry", vol. 81, no. 780, (2012).

[2] R. Ravisankar, K. Vanasundari, M. Suganya, Y. Raghu, A. Rajalakshmi, A. Chandrasekaran, S. Sivakumar, J. Chandramohan, P. Vijayagopal and B. Venkatraman, Appl. Radiat. Isot., vol. 85, no. 114, (2014).

[3] I. Akkurt, R. Altindag, T. Onargan, C. Basyigit, S. Kilincarsla, M. Kun, B. Mavi and A. Guney, Constr. Build. Mater., vol. 21, no. 2078, (2007).

[4] S. Rizzo, M. Brai, S. Basile, S. Bellia and S. Hauser, Appl,Radiat. Isot., vol. 55, no. 259, (2001).

[5] I. Shams, A. Mostafa and L. Abd El-Salam, J Radioanal.Nucl. Chem., vol. 303, no. 53, (2015).

[6] I. Shams, U. Mohamed and E. Reda, Turkish J Eng.Env.Sci, vol. 37, no. 109, (2013).

[7] United National Scientific Committee on the Effects of Atomic Radiation. Sources and Risks of Ionizing Radiation. Report to the General Assembly, with scientific annexes, United Nations, (2000).

[8] N. Ibrahiem, Journal of Environmental Radioactivity, vol. 43, no. 255, (1999).

[9] J. Beretka and P. J. Matthew, Health Phys., vol. 48, no. 87, (1985).

[10] D. Amrani and M. Tahtat, Appl. Radiat. Isot., vol. 54, no. 687, (2001).

[11] L. Xinwei, Radiation measurements, vol. 40, no. 94, (2005).

[12] A. Kumar, M. Kumar and S. Singh, "India radiation measurements", vol. 36, no. 465, (2003).

[13] O. B. Flores, A. M. Estrada, R. R. Sua'rez, J. T. Zerquera and A. H. Pe'rez, Environ. Radioact., vol. 99, no. $1834,(\mathbf{2 0 0 8})$.

[14] S. Stoulos, M. Manolopoulo and C. Papastefanou, J. Environ. Radioact., vol. 69, no. 225, (2003).

[15] B. Mavi and I. Akkurt, Radiat. Phys. Chem., vol. 79, no. 933, (2010).

[16] E. M. El Afifi, M. A. Hilal, S. M. Khalifa and H. F. Aly, "Radiation Measurment", vol. 41, (2006), pp. 627.

[17] M. Ngachin, M. Garavaglia, C. Giovani and M. G. KwatoNjock, "Radiation measurements", vol. 42, no. 61, (2007).

[18] S. Turhan and J. Environ, Radioact, vol. 99, no. 404, (2008)

[19] A. El-Taher, S. Makhluf, A. Nossair and A. S. Abdel Halim, Appl. Radiat. Isot., vol. 68, no. 169, (2010).

[20] M. Faheem, S. A. Mujahid and Matiullah, Radiat. Meas, vol. 43, no. 1443, (2008).

[21] R. G. Sonkawade, K. Kant, S. Muralithar, R. Kumar and R. C. Ramola, Atmos. Environ, vol. 42, no. 2254, (2008).

[22] M. N. Alam, M. I. Chowdhury, M. Kamal, S. Ghose, M. N. Islam, M. N. Mustafa, M. M. H. Miah and M. M. Ansary, J. Environ. Radioact, vol. 46, no. 243, (1999).

[23] V. Ramasamy, G. Suresh, V. Meenakshisundaram and V. Ponnusamy, Appl. Radioact. Isot., vol. 69, no. 184, (2011).

[24] A. El-Gamal and S. E. A. Nasr, Radioact. Meas., vol. 42, no. 457, (2007).

[25] L. S. Quindos, P. L. Fernandez, C. Rodenas, J. GomezArozamena and J. Arteche, Journal of Environmental Radioactivity, vol. 71, no. 139, (2004).

[26] N. Krishnamoorthy, S. Mullainathan, R. Mehra, M. A. Chaparro and M. A. Chaparro, Radiat. Prot.Dosimetry, DOI:10.1093/rpd/nct288, (2014).

[27] Naturally occurring radiation in Nordic countries - recommendation. In: The Flag-Book Series. The Radiation Protection Authorities in Denmark, Finland, Norway and Sweden, Reykjavik, (2000).

[28] European Commission (EC). Radiological Protection Principles Concerning the Natural Radioactivity of Building Materials. Radiation Protection Repotr No. 112. Directorate-General Environment. Nuclear Safety and Civil Protection, (1999).

[29] H. Taskin, M. Karavus, P. Ay, A. Topuzoglu, S. Hindiroglu and G. Karahan, Journal of Environmental Radioactivity, vol. 100, no. 49, (2009).

[30] United Nations Scientific Committee on the Effects of Atomic Radiation. Sources, effects and risk of ionizing radiation, United Nations, (1988).

[31] J. H. Zaidi, M. Arif, S. Ahmed, I. Fatima and I. H. Quershi, Appl. Radiat. Isot, vol. 51, no. 559, (1999).

[32] R. A. Groeneveld and G. Meeden, Statistician, vol. 33, no. 391, (1984).

[33] A. M. A. Adam and M. A. H. Eltayeb, J. Environ. Radioact., vol. 107, no. 23, (2012).

[34] I. Tanaskovi, D. Golobocanin and N. Milijevic, J. Geochem. Expl. 112 226, (2012). 
International Journal of Advanced Science and Technology Vol.82 (2015) 